\title{
Reproductive Tract Infections in Dairy Cows: Can Probiotics Curb Down the Incidence Rate?
}

\author{
Eduardo Barahona Rosales and Burim N. Ametaj * \\ Department of Agricultural Food and Nutritional Science, University of Alberta, Edmonton, \\ AB T6G 2P5, Canada; ebarahon@ualberta.ca \\ * Correspondence: burim.ametaj@ualberta.ca; Tel.: +1-780-492-9841
}

check for updates

Citation: Rosales, E.B.; Ametaj, B.N. Reproductive Tract Infections in Dairy Cows: Can Probiotics Curb Down the Incidence Rate? Dairy 2021, 2, 40-64. https://doi.org/10.3390/ dairy2010004

Received: 8 June 2020

Accepted: 4 January 2021

Published: 18 January 2021

Publisher's Note: MDPI stays neutral with regard to jurisdictional clai$\mathrm{ms}$ in published maps and institutional affiliations.

Copyright: $(\odot 2021$ by the authors. Licensee MDPI, Basel, Switzerland. This article is an open access article distributed under the terms and conditions of the Creative Commons Attribution (CC BY) license (https:// creativecommons.org/licenses/by/ $4.0 /)$.

\begin{abstract}
Postpartum uterine diseases are common in dairy cows and are a great concern for the dairy industry as they are associated with various consequences, including lower fertility, lower milk yield, and an overall negative impact on the host health. An infected uterus is a source of bacterial compounds and cytokines that spill into the systemic circulation, spreading inflammation to other organs. In this review article, we discuss a short overview of the anatomy of the reproductive tract of dairy cows and several infectious diseases of the uterus including metritis, endometritis, and pyometra. Additionally, we discuss the microbiome of the reproductive tract in health and during uterine diseases. As well, diagnostic criteria for metritis and endometritis and contributing factors for increased susceptibility to metritis infection are important topics of this review. To better understand how the uterus and reproductive tract respond to bacterial pathogens, a section of this review is dedicated to immunity of the reproductive tract. Both the innate and adaptive immunity systems are also discussed. We conclude the review with a factual discussion about the current treatments of uterine diseases and the new developments in the area of application of probiotics for uterine health. Mechanisms of actions of probiotics are discussed in detail and also some applications to prevent uterine infections in dairy cows are discussed.
\end{abstract}

Keywords: dairy cows; uterine infections; metritis; endometritis; pyometra; innate and adaptive immunity; probiotics

\section{Introduction}

Health issues during the periparturient period are encountered on a daily basis in dairy farm operations world-wide. Periparturient diseases are the major reasons for which dairy cows are culled in dairy farms [1]. According to Sheldon [2], uterine infections can affect almost half of dairy cows in a herd due to compromised immunity during the postpartum period. It should be noted that uterine diseases are multifactorial. Although it is not the objective of this review article to discuss those risk factors, some of the most important risk factors for metritis and endometritis are reviewed by Galvão [3], including parity (primiparity), twins, abortion, dystocia, retained placenta, still birth, male offspring, ketosis and hypocalcemia.

It has been reported that within $10 \mathrm{~d}$ after calving, around $21 \%$ of dairy cows develop uterine disease, such as metritis, due to the high numbers of pathogenic bacteria that ascend into the uterus postpartum [4,5]. Consequently, around $40 \%$ of the cows are not able to clear bacterial pathogens efficiently and develop endometritis [4,5]. Uterine diseases in dairy cows are classified as puerperal metritis, clinical endometritis or purulent vaginal discharge [5,6]. This classification is based on the time uterine infections occur with puerperal metritis occurring immediately after calving, metritis up to the first three weeks after calving, and subclinical endometritis more than 35 days in milk (DIM).

According to CanWest Dairy Herd Improvement (DHI) and Valacta [1], culling rates for reproductive issues of dairy cows in 2019 in Canada were 15.9\% (39,993 cows) / year out of a total of 621,509 cows registered with that company, out of $32.70 \%$ of the total culling 
rates. Therefore, understanding and lowering the incidence of uterine infections in dairy cows is one of the most challenging issue of the dairy industry world-wide, that needs concerted actions by the scientific community.

Economic loss models related to uterine diseases in dairy cows are difficult to find, due to different treatments used, labor costs, medication costs, prices of milk, veterinary bills, and discarded milk. An economic model adapted by Overton [7] estimated the loss in milk production, culling risk, and reproductive performance due to uterine infections at USD 386 per cow. It should be noted that even though the exact cost of uterine disease is difficult to calculate, the model presented by [7] serves as a basis to suggest that there is a need for improvements in the areas of prevention and early diagnosis of uterine diseases as well as in the management systems used by dairy producers.

\section{Short Overview of Reproductive Tract of Dairy Cows}

The reproductive tract of dairy cows is composed of the ovaries, oviducts, uterus, cervix and vagina, which altogether play important functions in the transport of gametes to the point of fertilization as well as the transport, development, and implantation of the developing embryo into the uterus [8]. It is also composed of external organs known to facilitate copulation and create all the necessary physical barriers to the potential entry of external pathogens. The reproductive tract is supported by the broad ligament, which acts as a suspensory tissue supporting the reproductive tract from the dorsal wall into the abdominal cavity [9].

The ovaries are connected to the fallopian tubes or oviducts where fertilization of the oocyte(s) takes place. Fertilization is usually considered to occur as the oocyte passes to the ampulla $[9,10]$. If the oocyte is fertilized, the developing zygote and embryo are transported into the uterus by means of ciliary action, where implantation will take place [9]. The posterior end of the uterus forms the only uterine opening known as the cervix also called the os uteri. The cervix will act as the first anatomical defense barrier preventing pathogens from entering the uterine lumen [11]. The cervix allows the passage of the sperm during mating for fertilization and during pregnancy it will be filled with mucus, establishing a cervical plug that is denoted as the second mechanical barrier that prevents detrimental pathogens from ascending into the uterus. In preparation for parturition, during the days prior to calving the cervical plug is expelled [9].

The uterus is divided into three layers: the perimetrium, myometrium, and the endometrium [12]. During the first 2-3 weeks after parturition, the size of the uterus decreases more than $80 \%$ of its pre-calving size; this process is very complex and managed by a variety of control structures that supports the process of uterine involution [13]. In a cow, the uterus plays various important functions including the transport of gametes and growth of embryo, recognition and support for the pre-implanted embryo, facilitation of placental development and attachment, and support for development of fetus until the time of parturition [9]. Close to parturition there is activation of the fetal hypothalamicpituitary-adrenal axis associated with increased production of corticotropin-releasing hormone (CRH) and adrenocorticotropic hormone (ACTH) which stimulate the production of fetal cortisol. Cortisol is carried to the maternal systemic circulation and initiates a cascade of events leading to parturition [9]. As part of this cascade, cortisol triggers a switch to progesterone/estradiol ratio with dominance of estradiol. Additionally, the onset of parturition starts more changes associated with increased response to oxytocin and increased uterine prostaglandin (PG)F $2 \alpha$ production. Post-partum, PGF2 $\alpha$ also triggers the process of involution and contractions of the uterus, helping expulsion of placenta within $24 \mathrm{~h}$ and uterine fluids $2-3$ weeks after parturition [14-16].

Subsequently, regeneration of the endometrium will be completed around 25 days after calving, if the elimination of bacteria by the host is successful. While a return of estrogenic state will allow for a return to the estrous cycle and normal ovarian cyclical activity, this might occur if the first dominant follicle is formed around 12 days after parturition [17-19]. 


\section{Bacterial Infection Postpartum}

It should be noted that endometrium of heifers and dairy cows contain a microbiome when they reach reproductive maturity [20]. The latter authors tested the hypothesis that virgin heifers and pregnant cows had a microbiome in the uterus (endometrium). They found presence of a microbiome in the uterus and proved that presence of three phyla including Firmicutes, Bacteroides, and Proteobacteria. They also demonstrated that several bacterial genera associated with uterine disease including Trueperella spp., Acinetobacter spp., Fusobacteria spp., Proteus spp., Prevotella spp., and Peptostreptococcus spp. were present in the uterus of virgin heifers and pregnant cows.

The vulva, vagina, and cervix serve as anatomical barriers that prevent bacterial pathogens to ascend to the uterus of dairy cows [21]. After parturition, the reproductive tract is opened due to the dilated state of the cervix and also inflamed. The latter allow bacteria to ascend from the external environment or through blood into the uterine lumen, which if persisting, can cause clinical diseases that might lead to subfertility and/or infertility [22]. A research article by Jeon et al. [23] indicated an association between blood microbiota and uterine pathogens, suggesting hematogenous spread of uterine infection in the early postpartum period. It has been shown that uterine bacterial infections are associated with lower conception rates, increased number of days opened, and increased culling rates [16,24]. Pathogenic bacteria found in the uterus have been reported to lower ovarian follicular growth and function [16]. A study conducted by Williams [4] supports this by providing evidence that ovarian folliculogenesis is disrupted by bacterial infection, meaning that the growth and function of the first dominant follicle is suppressed. Furthermore, uterine infections caused by bacteria will also result in delayed returning to estrus, and therefore, lower reproductive performance [25].

In the female reproductive tract, pathogenic bacteria that are present in the uterus [21] or that ascend from the vagina are the most common pathogens causing uterine infections [26]. A healthy or slightly inflamed uterus will clear pathogenic bacteria and keep its normal state by means of defense mechanisms during the first four to six weeks after parturition. Clearance of bacteria depends on various factors, such as uterine involution, uterine contractions, innate and adaptive immunity, and regeneration rate of the endometrium [22]. Issues during calving, retention of placental membranes, twin births, and germ-infested environments are some of the predisposing factors for uterine infections in dairy cows $[19,27-29]$.

\section{Reproductive Tract Microbiome in Health and Disease}

It has long been assumed that the uterus in its normal state is sterile [16,30]. Over the last decade data have emerged that challenge this belief. A recent study in human subjects [31] proved that most amniotic fluid samples and meconium contained bacterial DNA. This suggest that there are bacteria in the amniotic fluid and that the fetus microbiome is established after swallowing amniotic fluid during prenatal life [32,33]. This also is supported by the finding that microbiota of both the amniotic fluid and meconium are highly similar. To the best of our knowledge, there is no data to support this claim for dairy cows, yet.

Microbiota in the vaginal tract of dairy cows has been reported to be dominated by the Gram-negative family of Enterobacteriaceae. Lactobacillus spp. and Propionibacter spp. also have been found as part of the vaginal microbiota, although in lower numbers [34,35]. Other studies have reported presence of bacilli, staphylococci, and lactic acid bacteria (LAB) of the genera Enterococcus, Lactobacillus, and Pediococcus in the uterine microbiota of healthy and diseased cows. Interestingly, similar studies demonstrated that Escherichia coli and Trueperella pyogenes where also found in both the infected and healthy uteri of dairy cows, shortly after calving [36,37].

It should be noted that the abundance of Lactobacillus spp. in the vaginal mucus of dairy cows and ewes has been reported to be lower compared to human subjects [38]. Human vaginal microbiota is dominated by lactobacilli [39]. Another interesting difference 
between the cow and human vaginal environments are the slightly acidic to slightly alkaline $\mathrm{pH}$ of $6.8-7.35$ in dairy cows and an acidic $\mathrm{pH}$ in human subjects at $<4.5[38,40]$. It is believed that the low $\mathrm{pH}$ in the vaginal tract of humans is related to production of lactic acid by Lactobacillus spp. [40]. In humans the low vaginal $\mathrm{pH}$ maintains an environment that is hostile to many pathogens [40]. Bacterial vaginosis in humans is associated with a decrease in the abundance of Lactobacillus spp. and an increase in the vaginal $\mathrm{pH}$ [41]. Swartz et al. [39] showed that Lactobacillus spp. are present among vaginal microbiota of dairy cows ( $80-90 \%$ of cows), but at a very low relative abundance.

Truperella (formerly known as Arcanobacterium) pyogenes, E. coli, Fusobacterium necrophorum, and Prevotella melaninogenicus are known to cause uterine infections in postpartum dairy cows [42-45]. Although multiple studies have been conducted to classify pathogens that may cause uterine infections in dairy cows, to our best knowledge, only a recent article reported a complete overview of the microbiota of the entire reproductive tract (vagina and uterus) of dairy cows. Thus, Miranda-CasoLuengo et al. [46] compared the vaginal and uterine microbiomes of dairy cows at 7,21 and 50 days postpartum and showed a shared microbiota community in the vagina and uterus during the postpartum. Results also showed distinct microbiomes at 7 days after calving between healthy cows and those that developed endometritis at 21 days postpartum. Additionally, results showed that the microbiome of healthy cows displayed high content of Firmicutes whereas cows that developed endometritis had an increased level of Bacteroidetes. More interestingly the ratio of Firmicutes to Bacteroidetes in the healthy group and those that developed endometritis were 4.02 and 0.64 , respectively.

Interestingly, in the vaginal microbiota of women, primates, and rats the genus Lactobacillus is the predominant genus [47]. Anaerobic bacteria such as Bacteroidetes, Fusobacteria, Helcococcus, Filifactor, Porphyromonas, Peptoniphilus, Peptostreptococcus, Campylobacter, and Prevotella were found in the uterus of cows infected with metritis and are considered to contribute to the development of reproductive infections, especially bacterial strains of the phyla Bacteroidetes and Fusobacteria. Bacteria associated with uterine health such as Candidatus, Blochmannia, Escherichia, Sneathia, and Pedobacter were also found in the uterine fluids [22]. Other studies conducted by [48] report similar microbiomes in healthy and infected cows, the phyla composed mainly of Bacteroidetes, Fusobacteria, Firmicutes, Proteobacteria, and Tenericutes. In addition to these bacteria, sequences from Spirochaetes, Synergistetes, and Tenerella appear less frequently.

It is believed that fecal and vaginal bacteria are the main agents that cause reproductive tract infections in dairy cows; residues of these bacteria have been reported in the uterine fluids. Although E. coli is found in the microbiome of the bacterial community in both healthy cows and those with uterine infections, they were found in much greater numbers in infected cows [36].

Truperella pyogenes is a Gram-positive bacterium found in the mucus of reproductive, gastrointestinal, and respiratory tracts of dairy cows [35]. Host epithelial cells and macrophages are affected by $T$. pyogenes because they are able to survive within those cells for at least $72 \mathrm{~h}$. Moreover, expression of fimbriae and extracellular matrix binding proteins help these bacteria to attach to host cells and cause hemolysis and destruction of the cells [49]. It is also known that T. pyogenes secretes the exotoxin pyolysin (PLO) and cholesterol-dependent cytolysin (CDC), which can cause death of epithelial and immune cells by binding cholesterol in the cell membranes of eukaryotic cells forming pores and resulting in the death of the cell [50]. Additionally, T. pyogenes has the ability to secrete neuraminidase, which lowers mucous viscosity creating conditions for the pathogens to attach easily to the host [49].

E. coli is a Gram-negative bacterium found in greater numbers in cows with uterine infections [36,51]. Interestingly, E. coli has been found to be prevalent in the first week after parturition, triggering expression of interleukin- 1 beta (IL-1 $\beta$ ) and IL- 8 by endometrial epithelial cells [52]. Data reported by [4] stated that after parturition E. coli infections establishes a suitable environment for $T$. pyogenes to proliferate in the uterus of dairy 
cattle. A study conducted by Sheldon et al. [53] agrees with the aforementioned findings, that $E$. coli isolated from uterine lumen of dairy cows, 2 weeks after parturition, exacerbate, via synergistic actions with $T$. pyogenes, chronic uterine infections in dairy cattle. It should be noted that three different studies, conducted by $[36,51,54]$, reported enteropathogenic $E$. coli (EPEC), enterotoxigenic E. coli (ETEC), enterohemorrhagic E. coli (EHEC), and necrotoxic E. coli (NTEC) in the reproductive tracts of cows.

Fusobacterium necrophorum is a Gram-negative anaerobic bacterium usually found in the mucous membranes, which secretes leukotoxin and produces cytotoxic effects against immune cells [55]. Additionally, secretion of ecotin protein (a protease inhibitor), which has been known to be a potent anticoagulant, inhibits neutrophil elastase, which attacks bacteria at sites of inflammation and decreases plasma kallikrein, a component in the clotting cascade [55]. Several leukocytes, especially polymorphonuclear (PMN) cells, monocytes, macrophages, and dendritic cells (DC) are affected by leukotoxin, secreted by this pathogen, and it is believed to be the main virulence factor of this species [56,57]. In addition, F. necrophorum is categorized into two subspecies: F. necrophorum subsp. necrophorum $(F n n)$ presently known as biovar A and F. necrophorum subsp. funduliforme $(F n f)$ now known as biovar B [58]. F. necrophorum has been categorized as a commensal of the gastrointestinal, respiratory, and genitourinary tracts of animals $[57,59]$. F. necrophorum's outer cell membrane is composed of lipopolysaccharide (LPS), which is a bacterial membrane component composed of a polysaccharide chain known as the O-antigen and Lipid A, which is known to be toxic to dairy cows [60].

\section{Uterine Diseases of Dairy Cows}

\subsection{Metritis}

It is known that metritis is a great concern for dairy farmers worldwide. Given that metritis affects between $20 \%$ to $40 \%$ of cows in a herd, it has also a negative impact on productivity, longevity, and welfare of dairy cows [19]. Uterine infections can be evaluated by the physical characteristics and odor of the vaginal cervical mucus and a 0 to 3 ranking system has been proposed to evaluate the grade of metritis. According to [5,10], metritis can be ranked into 3 grades: Grade 1, characterized by having an enlarge uterus and an infection causing the cow to have a purulent uterine discharge within 21 days after parturition. Cows have no systemic signs of illness. Grade 2 metritis, in which signs of illness include fever $\left(>39.5^{\circ} \mathrm{C}\right)$, decreased milk yield, and a fetid red-brown uterine discharge. Puerperal metritis is highly associated with dystocia, retained placenta, twin births, and abortion, which occurs during the first week after parturition. Grade 3 metritis also known as puerperal or toxic metritis, in addition to the aforementioned signs for Grade 1 and 2 metritis, is associated with decreased feed and water intake, and can be associated with development of the downer cow syndrome [61-63].

Metritis is known as an inflammation of the uterus associated with different clinical signs including uterine discharges with foul-smelling (usually accompanied by blood), fever, decreased milk yield, and signs of toxemia [11]. Metritis also is associated with inflammation of the uterine wall within the first 21 days in milk (DIM) with the peak incidence between the first 10-14 days after calving. Potential pathogens associated with metritis such as E. coli, T. pyogenes, F. necrophorum, P. melaninogenica, and Proteus species have been found in the uterus of postpartum dairy cows $[4,64]$.

Metritis can cause irreversible changes in the reproductive tract of a cow and cause diseases that damage the endometrium causing infertility, due to the high content of pathogenic bacteria. Cows with metritis have higher concentrations of uterine LPS associated with prolonged luteal phase and decrease inflammatory responses in the endometrium [4].

Meanwhile, [9] reported that retention of fetal membranes is a risk factor for both metritis and endometritis. The same author indicated that the impact of retained placenta ranges from no effect to severe metritis. Strains of E. coli, Trueperella pyogenes, Fusobacterium necrophorum, and Prevotella melaninogenica are thought to be primary pathogens causing 
uterine disease, because these bacteria were frequently isolated from the uterine lumen of diseased cows, and they were shown to affect endometrium [65,66]. Interestingly, E. coli strains have been found on healthy and infected uteri in Holstein cows with metritis, although infected cows presented greater amounts of the pathogenic strains [34]. Bacterial contamination of the reproductive tract, after parturition, may be responsible for $90 \%$ of the infections in postpartum dairy cows [67]. Risk factors that are related to the disease are age, parity, calving season, environment, nutritional factor, calving conditions and retained placenta which makes the prevention of this pathology difficult to manage [51].

It has been observed that cows that develop metritis decrease feed consumption 3 weeks before and after parturition, therefore, milk yield and body condition score (BCS) tend to lower during the first two weeks postpartum. Cows with metritis have lower BCS than cows with a healthy status. Decrease in feed intake is an early indicator of metritis; and should be noted that during severe metritis Holstein dairy cows has been reported to lower the dry matter intake (DMI) up to $1 \mathrm{~kg}$ per day [68]. An increased risk of developing metritis is greater in cows that need assistance for calving due to the bacterial contamination [69]. After parturition cows with metritis have lower immunity, which further increases the risk of acquiring other diseases. Reproductive performance is affected negatively during metritis, delaying the return to a normal estrous cycle, causing infertility, and resulting in culled cows [51,64].

It has been reported that regardless of the periparturient period the $\mathrm{pH}$ median in the vaginal tract of Holstein cows tends to be around 7.50; however, in heifers the $\mathrm{pH}$ values tend to be slightly higher, around 7.75, during the first week after parturition, which may increase the odds to develop uterine infections due to the cervix's compromised state [70].

\subsection{Endometritis}

Endometritis is a localized inflammation of the endometrium whose principal causal agents are pathogenic bacteria $[5,71]$. Commonly, cows that have a detectable mucopurulent uterine discharge in the vagina, after 20 to 33 DIM, are considered to have endometritis $[5,24]$. Whitish or yellowish mucopurulent vaginal discharges (50\% pus and $50 \%$ mucus) are usually a clinical sign of endometritis. Traditionally endometritis has been defined as subclinical (SCE) and clinical endometritis (CE). However, recent studies have changed the terminology and definitions.

Clinical endometritis has been defined as local inflammation of the endometrium. It is commonly associated with presence of purulent or mucopurulent material, containing $>50 \%$ pus, in the vagina at or more than 21 days after calving. Those purulent discharges originate from uterus, and with no concurrent systemic disease [5,6]. Clinical endometritis commonly affects about $20 \%$ of dairy cows in a herd during 3-6 weeks after parturition [24]. Diagnosis of CE can be done by one of the following three techniques: (1) vaginoscope, (2) a gloved hand, or (3) the metri-check [72,73].

It should be noted that diagnosis of endometritis cannot be relied only upon appearance of abnormal vaginal discharges because they might not be related to inflammation of the endometrium alone. Therefore, it has been suggested that diagnosis of endometritis requires a combination of approaches including endometrial cytology, biopsy, or ultrasound examination [74]. The current term used for definition of vaginal discharges during endometritis, cervicitis, or vaginitis or a combination of all is purulent vaginal discharge (PVD) $[6,75]$. The incidences of endometritis, cervicitis and from both conditions are $13 \%$, $11 \%$, and $32 \%$, respectively [75]. All these inflammatory conditions, associated with PVD, affect the outcome of pregnancy by increasing it with 30 extra days [30].

Superficial inflammation of the endometrium is known as SCE. This condition similarly with CE has no systemic illness; however, it affects negatively reproductive performance of the cow [76,77]. Given that SCE is difficult to be diagnosed by general inspection of the cow, it is necessary to use some other diagnostic approaches including endometrial cytology, histopathology, leukocyte esterase strips (LES), and ultrasonography. It should be 
noted that the latter is not a very accurate way to diagnose SCE; therefore, it has been recommended that ultrasonography should be accompanied with endometrial cytology [76].

A known and confirmed procedure for the diagnosis of SCE is endometrial cytology. This procedure is based on counts of polymorphonuclear leukocytes (PMNs) in cytology slides. An elevated number of PMNs suggests an inflammatory response of the endometrium to infection. Some authors have proposed to define SCE as 'cytological endometritis' (CYTO). The threshold number of PMNs as diagnostic for SCE is related to time postpartum and ranges between 5-18\% [78]. Generally, it is accepted that a PMN value of $5 \%$ is an accurate way of diagnosis of CYTO between 21 and 62 days after calving. It should be pointed out that the accuracy and repeatability of PMN count has been evaluated and it is regarded as reliable. CYTO has been associated with detrimental effects on reproductive performance of the cow with a prevalence varying between $20-30 \%$ and is considered as the most important pathology of reproduction of dairy cows [77].

Two different procedures have been used in dairy cows to obtain an endometrial sample for cytological examination: the cytobrush $(\mathrm{CB})$ and low volume uterine lavage (LVUL) or flushing lavage $[79,80]$. The CB technique is used to sample cells from the vagina, cervix, or endocervix for counting PMNs. Similarly, a small of amount of uterine fluid $(2 \mathrm{~mL})$ is squeezed out of the uterus through rectal palpation and the fluid is collected. Smears are prepared for both CB and LVUL and stained with a modified Wright-Giemsa staining (Diff Quick) [81,82]. Then, cells present are examined.

Several studies have reported that the prevalence of clinical endometritis (CE) ranges between $18 \%$ to $37 \%$ of the herd [83-85]. Other studies focusing on subclinical endometritis (SCE) have reported the prevalence of infection ranging between $12 \%$ to $94 \%$ of the herd $[74,86,87]$. Subclinical endometritis can be evaluated and diagnosed by the percentage of polymorphonuclear (PMN) cells in cytological samples collected from the uterine lumen $[5,69,77]$. Cytological samples containing greater than 18\% PMN cells after 21 DIM, or greater than 10\% PMN at 34 DIM after parturition are considered as SCE [5]. Pathogens such as T. pyogenes, F. necrophorum, and Prevotella have been found frequently in the cytology samples of uterine lumens, increasing the risk of developing an endometritis after calving [44].

Another important method used to detect endometritis in postpartum dairy cows is the use of transrectal ultrasonography [76]. Ultrasonography measures the clarity of fluids from the uterus and the size of the body of the uterus. The measurements of the uterine horns at the base of the horn can be categorized as follows: small (less than $3.5 \mathrm{~cm}$ ), medium $(3.5-5.0 \mathrm{~cm})$, and large $(>5.0 \mathrm{~cm})$ [76]. LeBlanc et al. [24] reported sizes of uterus greater than $8 \mathrm{~cm}$ in diameter between 20 and 33 DIM in cows with uterine infections.

In another study conducted by [76], uterine cervical diameter was measured in 228 cows in two stages: V1 (20-33 DIM) and V2 (34-47 DIM). The cows in this study had uterine diameters for the V1 stage of $27.6 \%$ ( $<3.5 \mathrm{~cm}$ or small), $52.2 \%$ (3.5-5.0 cm or medium), and $21.5 \%(>5.0 \mathrm{~cm})$. Whereas for the V2 stage they found $68.4 \%(<3.5 \mathrm{~cm}$ or small), $28.1 \%$ $(3.5-5.0 \mathrm{~cm})$, and $3.5 \%(>5.0 \mathrm{~cm})$. These percentages clearly state that more than half of the herd had a normal uterine involution during the first 47 DIM and where diagnosed as healthy cows. Cows with longer duration of uterine infections result in decreased estrus detection as well as conception and pregnancy rates, and increased days to first service, which commonly leads to high culling rates in a herd $[24,76,77,88]$.

\subsection{Pyometra}

Pyometra has been defined "as the accumulation of fluid as well as purulent and mucopurulent exudate within the uterine lumen associated with a persistent corpus luteum and a closed cervix" [19]. The literal meaning of pyometra is pus-filled uterus. The disease is characterized by a suppurative infection and develops during the luteal phase and progesterone plays a key role in establishment of infection with ascending opportunistic bacteria. Persistent progesterone release from the corpus luteum plays a role in downregulating uterine immune functions and creates conditions for bacterial pathogens to 
succeed. The presence of infection stimulates PGE production and inhibits the release of PGF $2 \alpha$ from the endometrium and extends the luteal phase and is associated with infertility [67]. Additionally, progesterone production by the persistent corpus luteum causes closure of the cervix, leading to the enlargement and distension of the uterus due to the accumulation of exudates and pus in the lumen [71,89]. There are very few, if any, signs of systemic illness. An affected cow will not exhibit oestrus and is infertile [5,71]. Diagnosis of disease can be done by rectal ultrasonography.

Cultivation-base studies have shown that the most common pathogenic bacteria found in the purulent material of cows with pyometra have been reported to be F. necrophorum and T. pyogenes [19]. However, in a study conducted by [35] they reported a variety of bacterial families belonging to Fusobacteriaceae, Mycoplasmataceae, Bacteroidaceae, Porphyromonadaceae, and Pasteurellaceae that comprised $85 \%$ and $88 \%$ of the bacterial microbiota of the lumen and endometrium, respectively; suggesting a low diversity of bacteria in the uterus of cows affected by pyometra. Additionally, the authors demonstrated that the bacterial family that includes F. necrophorum (i.e., Fusobacteriaceae) and which is associated with endometritis and metritis, $[35,48,90]$, comprised the largest bacterial community in the pyometra cows. The authors concluded that their finding supports the association between species from the Fusobacteriaceae family and pyometra. However, the study was not able to confirm that the other family of Actinomycetaceae, which harbours T. pyogenes, was the second most important bacterial community, because they found that Actinomycetaceae accounted for $1 \%$ of the OTUs found in the uterine fluid samples of healthy and pyometra cows. Therefore, they suggested that more research is warranted to clarify the role of T. pyogenes in pyometra.

\section{Reproductive Tract Immunity}

\subsection{Innate Immunity of the Female Reproductive Tract}

In order to protect the fertilized ovum from any potential infection, it is important that the uterus and upper regions of the genital tract are guarded by immune-related mechanisms. Accordingly, the cervix is fortified with a variety of antimicrobial defense mechanisms to prevent entry of bacteria from the greatly colonized lower genital tract. Innate immunity plays an important role in protecting the endometrium from pathogenic bacteria and preventing uterine infections. Components of innate immunity involve the mucus layer, epithelial cell barrier, vaginal secretions, and antimicrobial peptides or molecules as well as a variety of immune cells. The mechanical aspect includes the process of desquamation and a mucus layer secreted by endometrial epithelial cells. The mucus layer prevents the direct attachment of bacteria to epithelial cells [91,92]. It is known that mucosal epithelial cells in the uterine tract act as protective barrier against bacterial pathogens. Mucus protects mucosal layers by binding and retaining the pathogenic agent as a physical and immunological barrier, preventing pathogens from entering further into the uterine tissues [74,93]. A study conducted by Carson et al. [8] reported that mucin glycoproteins Muc-1 found in mucus not only protects the host from infections but also is vital in the reproductive process. Cervical mucus is produced by goblet cells found in the cervix and some of the cervical mucus components are 5AC and 5B gel forming mucins present also in the mucus of the cow's reproductive tract (CRT) [94,95]. Cervical mucus usually mixes with the vaginal fluids also known as cervicovaginal mucus (CVM) [96]. Additionally, endometrial epithelial cells also are tightly bound to each other and at the same time prevent penetration of pathogenic bacteria through the epithelial cell layer. Desquamation of epithelial cells also is part of the reproductive tract innate immunity because it removes bacteria attached to the epithelial layer in a frequent manner.

The chemical barriers consist of secretion of a variety of antimicrobial peptides including lactoferrin, lysozyme, elafin, defensins, and secretory leukocyte protease inhibitor (SLPI), and a whole variety of defensins [77]. In addition, the chemical barrier involves pattern recognition receptors (PRR) like Toll-like receptors (TLR) and nucleotide-binding oligomerization domain (NOD)-like receptors (NLR) (NOD1 and NOD2) [67]. The PRR expressed in immune cells detect pathogen-associated molecular patterns (PAMP) and 
damage-associated molecular patterns (DAMPs) by the TLR system, which recruit immune cells that secrete cytokines and chemokines triggering an acute inflammatory response [92,97]. A study conducted by [98] reported presence of TLR1 through TLR10 in uterine horns and uterus of female humans, TLR1 through TLR9 in the vagina and cervix, which lead to production of IL-8 by epithelial cells.

Cells involved in innate immunity include neutrophils, macrophages, dendritic cells (DC), natural killer cells (NK), and mucosal epithelial cells [99]. Innate immunity is also known as the first line of defense consisting of mechanical, chemical, and cellular components [100,101].

Innate immunity in the reproductive tract plays an important role in the defense against Gram-negative bacteria, which usually are responsible for uterine infections. Neutrophils and epithelial cells produce neutrophil activating proteins (NAPs) that act as important immune responses against bacterial pathogens [102,103]. An example of NAPs in the mucus are defensins that play an important role in antibacterial activity, cell proliferation, and production of cytokines, chemokines, and modulation of adaptive and innate immune cells, which are moderated by estradiol and progesterone [79,104]. In the human reproductive tract, elafins and secretory leukocyte protease inhibitor, produced by macrophages and epithelial cells, have antimicrobial effects against bacterial pathogens [105]. Other components, such as lactoferrin and lysozyme, produced by neutrophils and epithelial cells, also play important roles inhibiting uterine infections and enforcing the innate immune system by producing antibacterial effects [101].

Antimicrobial peptides found in the vaginal mucus destroy the membrane of pathogenic bacteria as a defensive action directly related to $B$ and $T$ cells. Neutrophils interact with PRRs and other killing cells against pathogenic bacteria by the production of enzymes, nitric oxide, and reactive oxygen species (ROS) on postpartum cows with endometritis [16]. Consequently, the high production of $\mathrm{H}_{2} \mathrm{O}_{2}$ leads to the killing of pathogenic bacteria [106]. In addition, PRRs are also directly related to the TLR which manifest as neutrophils, macrophages, and DC's and detect pathogenic bacteria associated with immune stimulants such as LPS and peptidoglycan [99].

It should be noted that decreased recruitment of neutrophils and lymphocytes after parturition is known to be associated with uterine infections in dairy cows $[78,107]$. It is the endometrial tissue infected by pathogenic bacteria that responds first with macrophages. The latter are activated by bacterial compounds through the TLR system secreting a multitude of proinflammatory cytokines to attract many more cells to fight the infection of the endometrium [16]. The most important proinflammatory cytokines include TNF, IL-1 $\beta$, IL-6, IL-8, and IL-12 [108].

Presence of granular lymphocytes and macrophages has been reported in various regions of the endometrium of dairy cows [109]. Interestingly, studies conducted by [106] reported that monocytes stimulated by $E$. coli, in cows with uterine infections, have lower gene expression of key proinflammatory cytokines than healthy cows, 14 days after parturition. Additionally, the production of acute phase proteins (APPs) and the aforementioned cytokines help the host to fight inflammation but in excess they would be harmful to the host itself [110]. Furthermore, cows with metritis or clinical endometritis have higher circulating concentrations of adiponectin, leptin, TNF, IL-1-beta, and IL-6 compared to normal cows [111]. According to [112], there is a higher ratio of anti-inflammatory mediators such as IL-10, PGE, and transforming growth factor beta 1 (TGF- $\beta 1$ ), secreted by endometrial cells, and pro-inflammatory mediators such as IL-1 in infertile cows.

\subsection{Adaptive Immunity of the Female Reproductive Tract}

Adaptive immunity is a pathogen-specific immune response initiated by presentation of bacterial antigens, by antigen-presenting cells (APCs), to T- or B-cells. The main APCs in the female reproductive tract are macrophages, DCs, Langerhans cells, and epithelial cells of the cervix and endometrium [113]. This indicates that presentation of antigens in the CRT is mediated by both local resident cells and cells that migrate to the CRT from 
systemic circulation. Adaptive immunity of the FRT includes T helper type cell 1 (Th1) (cell-mediated), Th2 (humoral), T regulatory (Tregs), and Th17 responses.

Th1 cell-mediated immunity is involved in killing bacterial pathogens that enter inside host cells. There are two types of $\mathrm{T}$ cells: $\mathrm{CD} 8^{+}$and $\mathrm{CD} 4^{+}$cells. The $\mathrm{CD} 8^{+}$cells, known also as CTLs, are involved in killing host cells infected by pathogens and are driven by presentation of bacterial peptides on the surface of infected cells by MHC class I molecules. The killing of infected cells occurs through induction of apoptosis or cytolysis by perforin or granzyme molecules released by CTLs [114]. On the other hand, CD4 ${ }^{+}$cells produce large amounts of interferon (INF)- $\gamma$, which mediates cytotoxicity of $\mathrm{T}$ cells and blocks replication of viruses $[115,116]$. T cells are positioned below the epithelial cell layer or in-between them in the stroma of vagina, cervix, and uterus [117].

Reproductive tract Th2 humoral immunity involves production of pathogen-specific immunoglobulins that bind to pathogenic antigens that might be free or that associate with the pathogen itself. The humoral arm of adaptive immunity prevents potential attachment of pathogens to epithelial cells and their transgression into the host systemic circulation as well as neutralization of pathogens by binding and neutralizing their activity. Binding of specific immunoglobulins to the pathogen surface facilitates pathogen phagocytosis by macrophages or killing by the complement system. $\mathrm{CD}^{+}$cells play a crucial role in humoral immunity driving differentiation of $\mathrm{B}$ cell to antibody producing plasma cells [118]. Female reproductive tract is unique in the sense that unlike other mucosal surfaces secretes more IgG than sIgA $[119,120]$. Immunoglobulins present in the secretions of the genital tract are produced mainly locally but they also derive directly from serum by the process of transudation. These antibodies are able to prevent adhesion of pathogens to the epithelial cells and neutralize bacterial toxins and other potentially harmful antigenic compounds. They are also involved in antibody-dependent, cell-mediated cytotoxicity, and the promotion of phagocytosis by neutrophils.

$\mathrm{T}$ regulatory cells are $\mathrm{CD} 4^{+} \mathrm{T}$ cells and are also part of the FRT adaptive immunity. They are generated in the thymus gland. These cells are known for their anti-inflammatory activity or as suppressor-proinflammatory T cells like Th1, Th2, and Th17 [121]. Their inhibitory effects are either by inhibiting directly the effector $\mathrm{T}$ cells or by blocking APCs and consequently activation of effector $\mathrm{T}$ cells. The mechanism by which Tregs affect effector cells is by releasing cytokines or molecules that directly inhibit the functions of those cells. For example, Tregs compete with effector T cells for IL-2, a cytokine necessary for proliferation of both Tregs and effector $\mathrm{T}$ cells. Tregs also secrete anti-inflammatory molecules including IL-10 and TGF-beta which have similar effects on effector T cells.

Thelper type 17 cells are a distinct subset of $\mathrm{CD} 4^{+} \mathrm{T}$ cells that play an important role in regulating immune responses against bacterial and fungal pathogens in the FRT and other mucosal sites [122]. Th17 cells are lymphocytes that secrete mainly IL-17 [123]. In the presence of pro-inflammatory cytokines such as IL-6, regulatory T cells differentiate into Th17 cells that are involved in inflammation. Interleukin-17 is pro-inflammatory and induces expression of other pro-inflammatory cytokines and chemokines by stimulating other immune cells [121]. Additionally, Th17 cells are associated with neutrophil recruitment to the female reproductive tract and are critical for the clearance of pathogenic bacteria [124]. Th17 cells have also been shown to regulate neutrophil migration in mouse chlamydial infections and are thought to play a role in late-stage spontaneous abortion $[125,126]$.

\section{Treatment of Uterine Infections}

\subsection{Conventional Treatment of Uterine Infections}

Current treatment of uterine infections is based on utilization of a variety of antimicrobial compounds (Table 1). It should be noted that treatment of uterine infections with antibiotics, iodine solutions, and hormones has shown different efficacies [27]. Additionally, although antibacterial compounds help treat uterine bacterial infections there are several issues associated with their use. First, selection of antibiotic or medication drug to be used is very important and should be based on a lab testing of its efficacy prior to 
beginning of the treatment. Meanwhile the cow's health condition might be exacerbated. Second, selection of a single antibiotic or a combination of antibiotics and other drugs to be used for treatment needs in vitro testing in a lab to increase efficacy. Third, antibiotic or drug resistance of bacteria is growing which requires restricted use of antimicrobial compounds only for emergency cases. Fourth, antibacterial medications have the potential to be excreted through milk and therefore milk withdrawal should be applied. This has economic consequences on the dairy farm. Fifth, there is growing concern that food animal antimicrobial resistance might transfer to human bacteria and that it might lower efficiency for treatment of human emergencies. Therefore, exploration of alternative treatments to antimicrobial drugs is of utmost importance. Sixth, utilization of antibiotics or other drugs for treatment of uterine infections is associated with alterations in the composition of reproductive tract microbiota. For example, [127] reported that the use of ceftiofur was associated with important changes in the composition of microbiota at community, phylum, and genus levels, whereas ampicillin did not have an effect on uterine microbiota. Moreover, uterine Bacteroidetes were increased in cows treated with ceftiofur; but there were no changes in uterine microbiota in cows treated with ampicillin and in those left untreated. Additionally, treatment of cows with ceftiofur or ampicillin led to different outcomes with regard to abundance of Gram-negative genus Porphyromonas, which increased with ceftiofur and decreased with ampicillin use. Another interesting finding reported by [127] was that if metritis was not cured there was a decrease in the diversity of uterine microbiota and an increase in the relative abundance of Bacteroides, Porphyromonas, and Fusobacterium. It is not known whether the shifts in uterine microbiota driven by antibiotic treatment are restored to the original level or whether the imbalanced is permanent. Additionally, it is not known whether these microbiota shifts affect reproduction performance of cows treated with antibiotics.

Table 1. Treatment of postpartum uterine infections in dairy cows ${ }^{1}$.

\begin{tabular}{cccc}
\hline Uterine Infection & Antibiotics & Hormones & Disinfectants \\
\hline $\begin{array}{c}\text { Metritis, endometritis, } \\
\text { and pyometra }\end{array}$ & $\begin{array}{c}\text { Penicillin, ampicillin, ceftiofur, } \\
\text { oxytetracycline, cloxacillin, } \\
\text { aminoglycosides, nitrofurazone, } \\
\text { and sulfonamides } \\
+ \\
\text { Distilled water or saline }\end{array}$ & $\begin{array}{c}\text { 1. Prostaglandins and Estrogens } \\
\text { 2. Oxytocin and ergonovine }\end{array}$ & Iodine, chlorhexidine or cresol \\
\hline Application & Infusion and injection & Injection & Infusion \\
\hline Disadvantages & $\begin{array}{c}\text {-Microbial resistance } \\
\text {-Residues } \\
\text {-Production costs increase } \\
\text {-Endometrial irritation }\end{array}$ & $\begin{array}{c}\text {-Production costs increase } \\
\text {-Contraction of the uterus } \\
\text { regarding the size of the cervix }\end{array}$ & -Endometrial necrosis and \\
irritation of the epithelium
\end{tabular}

We refer the readers to some more recent studies that review, analyze, study or discuss in more detail utilization of antimicrobial compounds for treatment of various uterine infections in dairy cows as well as the efficiency of various antibiotics including ampicillin, ceftiofur and many more [134-136].

Although there are no preventive treatments developed to curb down uterine infections in commercial dairy farms, research work conducted by our lab and others indicate that using probiotic bacteria intravaginally might be beneficial and promising.

\subsection{Other Non-Conventional Treatments of Uterine Infections}

Besides conventional treatments for uterine diseases described above there has been various studies that have tested other non-conventional treatments against uterine infections. The philosophy behind these treatments is based on the fact that there is present a systemic inflammatory response in dairy cows around calving and especially during uterine diseases. Some of these studies have used oral anti-inflammatory treatments including non-steroidal anti-inflammatory drugs (NSAID) in the first week postpartum. Results 
of these studies have been mixed. One study reported negative effects on glucose and non-esterified fatty acids (NEFA) but positive effects on milk yield [137,138]. Another study that used acetylsalicylic acid several hours postpartum reported a lower prevalence of fetid vaginal discharge at 7-days postpartum [139]. On the other hand, another study using flunixin showed increased incidence of retained placenta and increased incidence of metritis [140].

Another area of research has been using granulocyte colony-stimulating factor, which is part of the growth factors family, and is known for stimulating conversion of hematopoietic stem cells to granulocytes. This compound has been used to trigger increase of neutrophil counts and their extravasation to the sites of inflammation [141]. Although compounds of this family have had some benefits with reduction of mastitis incidence they have been associated with greater incidence of lameness, displaced abomasum, and total clinical disease [142].

Given that the number of neutrophils lowers during uterine infections, another compound that has been tried to improve this deficiency has been interleukin-8 (IL-8). Interleukin-8 is known for his chemoattractant properties toward neutrophils. Intrauterine infusion of recombinant bovine IL-8 (rbIL-8) by $[143,144]$ within $24 \mathrm{~h}$ postpartum was reported to increase proportion of neutrophils in the vagina and uterine lumen and lower the prevalence of puerperal metritis in multiparous cows but had no effect on the incidence of retained placenta. The reader is referred to [145] for more details on this field of research.

\subsection{Intravaginal Probiotics: A New Approach to Preventing Uterine Infections}

The Food and Agriculture Organization of the United Nations (FAO) defines the term "probiotics", as live microorganisms that, when administered in adequate amounts, confer a health benefit on the host [146]. Probiotics have a positive effect in the gastrointestinal and genitourinary flora decreasing the growth of pathogens by antimicrobial properties. Lactobacillus spp. has been known as one of the most important and the most studied beneficial microorganisms in treating bacterial vaginosis and urinary tract infections in the CRT [147].

It should be noted that the microbiota of the vaginal tract of dairy cows is not dominated by Lactobacillus strains as is the vaginal tract of female subjects [148]. There is also a difference in the vaginal $\mathrm{pH}$ between dairy cows and human vaginal $\mathrm{pH}$, with cows having a slightly acidic to slightly alkaline neutral or slightly alkaline value ( $\mathrm{pH}$ 6.8-7.35) and humans having an acidotic vaginal $\mathrm{pH}(3.5-4.5)$ [143]. Lactobacilli are known to produce lactic acid through hydrolysis of glycogen present in vaginal mucosa and lower the vaginal $\mathrm{pH}$ to acidic values, which is unique to humans [148]. Acidic vaginal $\mathrm{pH}$ plays a significant role in the prevention of bacterial infection [143]. It should be noted that, Lactobacilli use glycogen, released by vaginal epithelial cells to produce lactic acid. Interestingly, glycogen has been reported also in the vaginal tract of dairy cows [149]. Given that lowering vaginal $\mathrm{pH}$ is a physical barrier to pathogenic bacterial infection several studies in dairy cows have explored the potential of using intravaginal Lactobacilli to prevent vaginal and uterine infections.

A study conducted by our lab applied intravaginally a mixture of three strains of LAB in transition dairy cows around calving. A total of 82 cows were split into 2 experimental groups (41 cows per group). The control group was treated with $1 \mathrm{~mL}$ of carrier (sterile skim milk) and the treatment group was treated with $1 \mathrm{~mL}$ of a mixture of three lactobacilli including Lactobacillus sakei, Pediococcus acidilactici FUA 3140, and P. acidilactici FUA 3138 at $10^{10}-10^{12} \mathrm{CFU}$ of $\mathrm{LAB} / \mathrm{wk} / \mathrm{cow}$. Six treatments were administered intra-vaginally at week 2 and 1 prior to parturition and at weeks 1-4 post-partum, on a weekly basis. Lactic acid bacteria were recovered from the mucus of the vaginal tract of healthy multiparous dairy cows [36]. Results of this study proved for the first time in dairy cows that intravaginal probiotics could lower the occurrence of purulent vaginal discharges (PVD) [150]. There was no effect of treatment on pregnancy rate. Interestingly, administration of LAB lowered plasma haptoglobin, an indicator of uterine infections, and also increased milk yield from multiparous cows by $3 \mathrm{~kg} / \mathrm{d}$ for the first $50 \mathrm{DIM}$. 
In a second study conducted by our lab a total of 100 cows were randomly assigned to 3 groups. Three groups of cows ( $n=33$ cows per group) were treated either with carrier alone (sterile skim milk) or with 2 doses of LAB only prepartum and 1 dose of carrier (treatment 1 ) or 2 doses of LAB prepartum and 1 dose of LAB after calving (treatment 2). The same mixture of LAB (composed of L. sakei FUA3089, P. acidilactici FUA3138, and $P$. acidilactici FUA3140 with a cell count of $10^{8}-10^{9} \mathrm{cfu} /$ dose) were administered intravaginally to the two treatment groups. Data demonstrated that cows treated with $\mathrm{LAB}$ had lower incidence of metritis and total uterine infections (i.e., metritis, clinical endometritis, and pyometra) and also lower systemic lipopolysaccharide binding protein (LBP) and tended to have lower systemic serum amyloid A (SAA) and higher vaginal mucus SIgA [51]. Moreover, data from the same study showed that intravaginal LAB expedited uterine involution, as indicated by smaller size of uterine horn and body in the treated cows at 14 days postpartum. In this study we confirmed that intravaginal LAB were able to increase milk yield and feed efficiency in the treated cows [151]. LAB-treated cows in the same study had higher concentrations of $\operatorname{IgG}$ and lower concentrations of $\mathrm{Hp}$ in the milk at 3 DIM (i.e., colostrum) compared with cows that were left untreated. Interestingly, intravaginal LAB lowered concentrations of NEFA in the serum of the treated cows. High concentrations of NEFA in the blood around calving have been associated with negative energy balance and fatty liver [152].

A third study by our lab confirmed again the positive effects of intravaginal probiotics in a larger number of cows and multiple dairy farms ( 3 conventional Holstein herds and 1 organic Jersey herd) by lowering the incidence rate of uterine infections by $29 \%$ (Barahona and Ametaj, 2018-unpublished data). Interestingly, the decrease in the incidence rate of uterine infections in the organically managed Jersey herd was $50 \%$. As an average, all dairy cows treated with intravaginal LAB produced $4.0 \mathrm{~kg}$ milk/day more than untreated cows for the first 56 DIM.

In a similar study conducted by [153], using a mixture of three commercially available $\mathrm{LAB}$, they confirmed that intravaginal probiotics lowered the incidence of uterine infections by $60 \%$. Genis et al. [153] also tested in vitro the potential role of LAB in the prevention of endometrial cell infection by E. coli. Indeed, results showed that E. coli infection was lowered by $83 \%$ in presence of Pediococcus acidilactici in vitro. Lactobacillus sakei lowered infection of endometrial cells by $87 \%$. Lactobacillus rhamnosus and L. reuteri lowered infection of endometrial cells by E. coli by $38 \%$ and $78 \%$. The authors reported that one potential mechanism for prevention of $E$. coli infection was enhanced expression of occludin (a tight junction protein) by several fold by all the aforementioned LAB. Genís et al. [153] also confirmed previous findings by [150], and [51] and concluded that probiotics composed of LAB and infused intravaginally in dairy cows, lowered the prevalence of metritis by $62 \%$ over dairy cows that were not treated. Differences were found in reducing the blood concentration of IL-1 $\beta$, IL-6, IL-8 and TNF, which are inflammatory mediators.

Genís et al. [153] also conducted mechanistic studies in vitro to better understand how the LAB affect endometrial cell response during E. coli infections. They used three doses of $\mathrm{LAB}$ of a combination of $4 \mathrm{LAB}$ (L. rhamnosus, P. acidilactici, L. reuteri, and L. sakei). Results indicated that the dose of $\mathrm{LAB}$ used is important with regard to easing or aggravating the inflammation induced by $E$. coli infection. Overall results indicated that the best combination of $\mathrm{LAB}$ to ease $E$. coli inflammation and infection was utilization of $L$. rhamnosus at ratio 25 , P. acidilactici at ratio 25 , and L. reuteri at ratio 2 (The ratio of each $L A B$ corresponds to the number of $\mathrm{LAB} /$ epithelial cell in vitro).

\subsection{Mechanisms of Action of Probiotics}

Lactic acid bacteria are anaerobic Gram-positive bacteria that lack catalase, and that ferment glucose to lactic acid, $\mathrm{CO}_{2}$, and ethanol. They grow anaerobically as aerotolerant anaerobes and since they lack catalase, peroxide radicals are detoxified by means of peroxidase enzymes [154]. Moreover, it is commonly accepted that LAB increase micro- 
biological, physiological, and immunological defenses on commensal bacteria and the immune system [154].

The host benefits from $\mathrm{LAB}$ due to their capacity to inhibit or eliminate pathogens through the production of a multitude of compounds including organic acids, bacteriocins, and various antimicrobial compounds $[155,156]$. The production of antimicrobial substances by $\mathrm{LAB}$ maintains the vaginal $\mathrm{pH}$ at acidic value creating a hostile environment for the growth of pathogenic bacteria [36,157-159].

One of the most studied antimicrobial peptides produced by probiotic bacteria is bacteriocin. Production of bacteriocin is regarded as an important trait for selection of probiotic bacteria. Bacteriocins are peptides that have a multitude of actions including: (1) serving as colonizing peptides, (2) acting as killing peptides, or (3) playing the role of signaling molecules [160]. Production of bacteriocins may give probiotics a competitive advantage against antagonistic bacteria or create favorable conditions for cooperative microorganisms in a specific mucosal layer. The ability of bacteriocins to inhibit growth of pathogenic bacteria has been well documented [161-163]. In a study conducted by our team we evidenced the effect of several strains of pediocin-producing Pediococcus acidilactici on growth of Enterococcus faecalis FUA3141. Indeed, data showed that Ped. acidilactici FUA3138 and FUA 3140 produced inhibition zones against E. faecalis. Additionally, probiotic peptides might serve as quorum sensing peptides that at higher concentration act as inhibitors and at low concentrations as signaling compounds [164]. Studies conducted by Meijerinket al. [165] and van Hemert et al. [166] identified genes in Lactobacillus plantarum that may influence the activity of dendritic cells and neutrophils. Deletion of those genes was shown to change substantially the cytokine profile of the host. Those genes were involved in bacteriocin production and secretion.

Besides bacteriocins, probiotic bacteria have a multitude of other means of providing the host and themselves advantages over pathogenic bacteria. Some of the most important mechanisms of action of probiotics that benefit the host include: (1) strengthening of epithelial barrier functions; (2) establishing biofilms on mucosal layers; (3) preventing adhesion of pathogens; (4) competing for essential nutrient; (5) production of anti-microbial compounds; (6) modulation of the immune system; (7) changing of vaginal $\mathrm{pH}$ [167].

\subsubsection{Strengthening Epithelial Barrier Functions}

Probiotic bacteria are involved in enhancing epithelial barrier functions by increasing expression of genes involved in tight junction signaling [168]. For example, lactobacilli have been shown to influence expression of genes related to adherence junction proteins, such as E-cadherin and $\beta$-catenin, in a T84 cell barrier model. Likewise, incubation of intestinal cells with lactobacilli differentially influences the phosphorylation of adherence junction proteins and the abundance of protein kinase $\mathrm{C}$ (PKC) isoforms, such as PKC $\delta$, thereby positively modulating epithelial barrier function [169].

\subsubsection{Adhesion on Epithelial Layers}

Adhesion of probiotics to mucosal layers is one of the desired characteristics for their selection. Probiotic bacteria compete with pathogens for niches, and if they have good adherence capabilities they can block adherence of pathogens. The adhesion of probiotics also is important, because it creates the possibility of interaction with the host and establishment of colonies on epithelial layers [170-172]. Lactobacilli secrete several proteins that function as mucus binding proteins that help adhesion of probiotics. Thus, several proteins from Lactobacillus spp. have been shown to interact with mucous layers [173]. In this regard, several studies have shown the inhibitory effects of Lactobacillus rhamnosus LGG against vancomycin-resistant enterococci (VRE) in human patients [174,175]. Moreover, [176] demonstrated a new mechanism of how L. rhamnosus GG inhibits binding of Enterococcus faecium and its decolonization. The authors showed that one of the VRE pilus structures shares structural similarity with mucus binding SpaCBA-Srtc1 pilus cluster of L. rhamnosus GG. Indeed, both L. rhamnosus GG and VRE express pili on their cell wall, 
which bind to mucus secreted by the host. L. rhamnosus GG pili are able to prevent binding of VRE to the host. The authors indicated that the mechanism discovered supports both the recognized mechanism of competitive exclusion and a new mechanism of induction of cross-immunity activity against bacterial pathogens.

Another interesting mechanism of the adhesion characteristic of probiotics is their ability to attach to other bacteria of different species known as the co-aggregation or with the same species known as auto-aggregation [177]. Several studies have revealed that the protective role of probiotics is exercised by bringing pathogenic bacteria together into co-aggregates and by preventing establishment of biofilms, which is a form of existence and survival of pathogenic bacteria [178]. A study by [179] reported that two probiotic strains of $L$. reuteri co-aggregated with Candida albicans, during the process of biofilm development, creating an unfavourable environment that inhibited the growth of yeast.

\subsubsection{Competing for Essential Nutrients}

Probiotic bacteria use a whole variety of mechanisms to compete for mucosal sites and nutrients with pathogenic bacteria. Competing for essential nutrients is of utmost importance for survival of probiotics and for starving and harming pathogenic bacteria. Nutrients are crucial for bacterial growth and creation of an unfavourable environment. This phenomenon is known as competitive exclusion and has beneficial effects on a multitude of mucosal layers where microbiota play significant roles on host health, including the genital tract. Several studies in human subjects have shown that probiotic bacteria are helpful for treatment and prevention of genital infections [180-183]. In this regard, some clinical trials in humans have reported a temporary colonization of probiotic bacteria in the vagina and have proven that probiotics are beneficial for prevention of bacterial vaginosis [184-186].

\subsubsection{Production of Organic Acids}

Other mechanisms involved in the health benefits provided by probiotics include production and release of organic acid like lactic acid and acetic acid. When compared to lactic acid, acetic acid has a broader spectrum of antimicrobial activity. In this regard, it is known that there is a synergistic effect of both acids and that mixtures of acetic and lactic acid suppress growth of the pathogenic Gram-negative enteric bacterium like Salmonella typhimurium [187]. Lactic acid and acetic acid have a strong inhibitory effect on Gram-negative bacteria, and they have been considered very important compounds responsible for some of the inhibitory activity of probiotics against pathogens [188-190]. The mechanism by which organic acids damage pathogenic bacteria is related to entering of the undissociated form of the organic acid into the bacterial cell and then dissociating inside pathogenic cytoplasm. The subsequent lowering of pathogen's intracellular $\mathrm{pH}$ or accumulation of the ionized form of the organic acid leads to death of the pathogenic bacterium $[191,192]$. It has been shown that the L-isomer form of lactate has greater inhibitory activity against pathogens than D-isomer [193]. It should be noted that bacteria respond in different ways to the acidity of the environment. For instance, if the environmental $\mathrm{pH}$ lowers $<5.0$, lactic acid can inhibit the growth of spore-forming bacteria, but it has no effect on the growth of fungi or yeasts.

\subsubsection{Production of Antimicrobial Substances}

Lactobacilli produce a multitude of inhibitory and antimicrobial substances to prevent infection of the vaginal mucosa caused by pathogenic bacteria [194]. Lactobacilli are known to produce bacteriocin-like substances and small antibacterial peptides (AMPs). The mechanisms of action of bacteriocins were explained at the beginning of this section; however, the common mechanisms of bacteriocin-mediated killing include the destruction of target cells by pore formation and/or inhibition of cell wall synthesis [195].

Lactobacilli isolated from healthy vaginal swabs have been shown to have antimicrobial activity in vitro against Salmonella, Gardnerella, Enterococcus, and Neisseria by the 
production of antimicrobial substances [194]. Additionally, Lactobacillus salivarius is able to produce a bacteriocin (ABP-118), which has bacteriostatic effects on the growth of a variety of pathogens including Bacillus, Listeria, Enterococcus, and Staphylococcus species. It is interesting to note that the growth of most Lactobacillus species is not inhibited by these antimicrobial peptides, thus imparting a selective advantage against pathogenic bacteria [196]. Lactobacillus lactis also produces a two-peptide bacteriocin (i.e., lacticin 3147). Lacticin is able to establish selective ion pores having a broad-spectrum bacteriostatic effect on Gram-positive bacteria, including isolates of Clostridium difficile [197-199].

Another antimicrobial compound is hydrogen peroxide $\left(\mathrm{H}_{2} \mathrm{O}_{2}\right)$ is an inhibitory compound against different pathogens. It catalyzes the oxidation of halides by peroxidases which results in the formation of metabolites with a potent toxicity, i.e., the corresponding hypohalous acid or halogen [200]. Early studies have shown that vaginal Lactobacillus spp. have the capability to produce substantial amounts of $\mathrm{H}_{2} \mathrm{O}_{2}$ in vitro. For example, [201] showed that almost $80 \%$ of the vaginal Lactobacillus spp. in healthy human females were able to produce $\mathrm{H}_{2} \mathrm{O}_{2}$. Furthermore, a study [202] conducted in 215 sexually active women revealed that $\mathrm{H}_{2} \mathrm{O}_{2}$ was produced by $95 \%$ of L. crispatus and $94 \%$ of $L$. jensenii vaginal isolates. In pregnant females, $\mathrm{H}_{2} \mathrm{O}_{2}$-producing Lactobacilli seem to protect them against the development of bacterial vaginosis, being an important bacterial group to maintain an ecologic balance [203]. Of note, it has been suggested that under low oxygen conditions of the vagina, the concentration of $\mathrm{H}_{2} \mathrm{O}_{2}$ is unlikely to attain toxic levels that inhibit pathogenic microorganisms [204]. Additionally, a study by [205] indicated that the activity of $\mathrm{H}_{2} \mathrm{O}_{2}$ can be reduced by fluids secreted by the vaginal tract, implying that production of $\mathrm{H}_{2} \mathrm{O}_{2}$ by vaginal lactobacilli might not be of significance for in vivo protection.

\subsubsection{Modulation of Immune System}

Many beneficial effects of lactobacilli are related to their ability to redirect the host immune responses. Human research in vitro has shown that L. crispatus [206-208] and L. jensenii [209] act both through colonization of epithelial cells and modulating secretion of various cytokines. For example, secretion of IL-8 is inhibited, whereas release of interleukin (IL)-10, IL-6, and defensins are induced ensuring homeostasis of immune responses. Interestingly, L. crispatus SJ-3C-US strain, was shown to up-regulate production of IL-10 by dendritic cells, which is known to have anti-inflammatory functions [210]. It has been shown that many of the immune effects of lactobacilli are related to lactic acid. Thus, lactic acid has been shown to suppress inflammatory responses from vaginal and cervical epithelial cells by inhibiting secretion of IL-6, IL-8, RANTES, and TNF- $\alpha$ secretion, which are released by the host in response to presence of pathogenic bacteria [211]. Both L- and D-lactic acid isomers have been shown to mediate the anti-inflammatory effects [211,212].

There is scarcity of data with regard to in vivo effects of probiotics on immune modulation. Two lactobacilli strains including Lactobacillus salivarius CRL 1328 and L. gasseri CRL 1263 have been proposed as good candidates for keeping a balanced vaginal microbiota and engaging host immunity. In humans, Hemalatha et al. [213] and Mastromarino et al. [214] have demonstrated that intravaginal Lactobacillus tablets lower concentrations of proinflammatory cytokines IL-1 $\beta$ and IL- 6 in both healthy women and women affected by bacterial vaginosis. In another study conducted by De Gregorio et al. [215] and involving mice infused intravaginally with lactobacilli, no effect was reported on the number of vaginal washing granulocytes and macrophages.

In a study conducted by our lab in dairy cows infused intravaginally multiple times around calving with a mixture of three lactobacilli, it was observed that both local and systemic immunity were modulated [51]. The data showed that intravaginal lactobacilli lowered concentrations of systemic lipopolysaccharide binding protein (LBP), and increased vaginal mucus secretory immunoglobulin A(sIgA). There was also a tendency for systemic serum amyloid A (SAA) to be lower in the treated cows. There were no differences found in the serum concentrations of haptoglobin (Hp), TNF, IL-1, IL-6, and total IgG between the lactobacilli-treated groups and the control cows. 
An early study conducted by [216] reported the effects of infusing in the uterus two probiotic bacteria in separate groups. The first group received in the uterus $20 \mathrm{~mL}$ of $1 \%$ glucose and the strain of Lactobacillus spp. G $013\left(5.5 \times 10^{8}\right) \mathrm{CFU} / \mathrm{mL}$ and another group was treated similarly with Lactobacillus casei CCM $1753(1.2 \times 108 \mathrm{CFU} / \mathrm{mL}$. Control cows received only $20 \mathrm{~mL} 1 \%$ glucose solution. Treatment was applied 8-12 days of the estrus cycle. Endometrial tissue samples were collected at 5-6 and 10-12 days after treatment. Results showed that Lactobacilli colonized the uterus of the treated cows for up to 12 days post-treatment. Additionally, the authors reported infiltration of mononuclear cells especially mast cells and macrophages in the uterus. No differences were observed on the effects of the two lactobacilli used. The authors suggested to use lactobacilli for prevention of endometritis.

\subsubsection{Changing Vaginal $\mathrm{pH}$}

It is known that the vaginal lactobacilli of female humans have the ability to produce lactic acid through the fermentation of sugars, leading to a low $\mathrm{pH}$ which prevents the proliferation of microorganisms that can cause urogenital infections [217,218]. However, this is not true for the vaginal $\mathrm{pH}$ of dairy cows, which as already indicated previously, is not dominated by lactobacilli and has an alkaline $\mathrm{pH}$ in periparturient cows at around 7.50 [71]. Besides creating a hostile environment for pathogenic bacteria, the acidic $\mathrm{pH}$ supports growth of lactobacilli [154]. These data support the reported findings, by our team and others $[158,159]$ on the beneficial effects of infusing lactobacilli into the vaginal tract of dairy cows in lowering the incidence of uterine infection. For example, Pediococcus pentosaceus SB83 has been shown to lower the vaginal $\mathrm{pH}$ values from 6.5 to 4.2 within a period of $24 \mathrm{~h}$ [219]. Additionally, Boris et al. [220] and Tomás et al. [221] have demonstrated that acidification of the vaginal tract can inhibit the growth of pathogenic bacteria including Gardnerella vaginalis and E. coli, related to infection of the urogenital tract.

\section{Conclusions}

During the first weeks after parturition the uterus is exposed to a whole variety of pathogenic bacteria, which cause a multitude of infectious diseases. Some of the uterine infectious diseases include metritis, endometritis, and pyometra. Several strains of both Gram-negative and Gram-positive pathogenic bacteria have been identified as the main causative agents of uterine infections. Infectious diseases of the uterus affect directly the fertility and productivity of dairy cows and consequently the financial bottom line of dairy industry. The current medication of uterine infections includes systemic utilization of antibiotics. Given public concern with respect to development of antibiotic resistance, new alternatives for preventing uterine infections have been explored by several research labs during the last 5 years. In this review article we present the potential of probiotics as a 'green' technology to lower the incidence of uterine infections in dairy cows and give several examples of how intravaginal lactobacilli have lowered uterine infections and have improved immune responses and milk yield. The mechanisms of how intravaginal lactobacilli lower infection by pathogens and improve the health of dairy cows is related to a multitude of actions that that have been discussed in detail in this article. There is much knowledge with regard to probiotic-host interactions in human research and less such knowledge in cattle. There are differences between the vaginal microbiota of human females and dairy cows. Therefore, more research in this area is of utmost importance to better understand the benefits and the mechanism(s) of action of probiotics in the reproductive tract of cattle.

Author Contributions: Conceptualization, B.N.A. and E.B.R.; resources, B.N.A.; writing-original draft preparation, E.B.R.; writing-review and editing, B.N.A.; supervision, B.N.A.; project administration, B.N.A.; funding acquisition, B.N.A. All authors have read and agreed to the published version of the manuscript. 
Funding: This research was funded by Alberta Livestock and Meat Agency Ltd. grant number 2015B007R.

Institutional Review Board Statement: Not applicable.

Informed Consent Statement: Not applicable.

Data Availability Statement: No data available. This is a review article.

Conflicts of Interest: The authors declare no conflict of interest.

\section{References}

1. CanWest DHI and Valacta. Culling and Replacement Rates in Dairy Herds in Canada. 2019. Available online: https://www. infolait.gc.ca/resources/prod/dairy/pdf/genetics-cull_e.pdf (accessed on 5 June 2020).

2. Sheldon, I.M.; Cronin, J.; Goetze, L.; Donofrio, G.; Schuberth, H.J. Defining postpartum uterine disease and the mechanisms of infection and immunity in the female reproductive tract in cattle. Biol. Reprod. 2009, 81, 1025-1032. [CrossRef]

3. Galvão, K.N. Uterine diseases in dairy cows: Understanding the causes and seeking solutions. Anim. Reprod. 2013, 10, 228-238.

4. Williams, E.J.; Fischer, D.P.; Pfeiffer, D.U.; England, G.C.; Noakes, D.E.; Dobson, H.; Sheldon, I.M. The relationship between uterine pathogen growth density and ovarian function in the postpartum dairy cow. Theriogenology 2007, 68, 549-559. [CrossRef]

5. Sheldon, I.M.; Lewis, G.S.; LeBlanc, S.; Gilbert, R.O. Defining postpartum uterine disease in cattle. Theriogenology 2006, 65, 1516-1530. [CrossRef] [PubMed]

6. $\quad$ Dubuc, J.; Duffield, T.F.; Leslie, K.E.; Walton, J.S.; LeBlanc, S.J. Definitions and diagnosis of postpartum endometritis in dairy cows. J. Dairy Sci. 2010, 93, 5225-5233. [CrossRef] [PubMed]

7. Overton, M.W.; Fetrow, F. Economics of postpartum uterine health. In Proceedings of the 2008 Dairy Cattle Reproduction Council Convention, Omaha, NE, USA, 7-8 November 2008; pp. 24-29.

8. Carson, D.D.; DeSouza, M.M.; Kardon, R.; Zhou, X.; Lagow, E.; Julian, J.A. Mucin expression and function in the female reproductive tract. Hum. Reprod. 1998, 4, 459-464. [CrossRef] [PubMed]

9. Senger, P.L. Pathways to Pregnancy and Parturition, 2nd ed.; Current Conceptions, Inc.: Pullman, WA, USA, 2009 ; pp. 10-226.

10. Sheldon, I.M. The Metritis Complex in Cattle. Veterinary Reproduction and Obstetrics, 10th ed.; Elsevier: Milton, ON, Canada, 2019; pp. 408-432.

11. LeBlanc, S.J. Postpartum uterine disease and dairy herd reproductive performance: A review. Vet. J. 2008, 176, 102-114. [CrossRef] [PubMed]

12. Budras, K.D. Bovine Anatomy: An Illustrated Text; Schlütersche: Hannover, Germany, 2003; p. 138.

13. Klingborg, D.J. Facts and fallacies about the uterus after calving. Veterinary medicine. J. Agric. Sci. Technol. Inf. 1996, 8, 189-195.

14. Deutscher, H. Reproductive Tract Anatomy and Physiology of the Cow; Historical Materials from University of Nebraska-Lincoln Extension: Lincoln, NE, USA, 1980; p. 315.

15. Kindahl, H.; Banaka, M.; Kask, K.; Konigsson, K.; Gustafsson, H.; Odensvik, K. Endocrine aspects of uterine involution in the cow. Reprod. Domest. Anim. 1999, 34, 261-268. [CrossRef]

16. Sheldon, I.M.; Dobson, H. Postpartum uterine health in cattle. Anim. Reprod. Sci. 2004, 82-83, 295-306. [CrossRef]

17. Savio, J.D.; Boland, M.P.; Hynes, N.; Roche, J.F. Resumption of follicular activity in the early postpartum period of dairy cows. J. Reprod. Fertil. 1990, 88, 569-579. [CrossRef]

18. Beam, S.W.; Butler, W.R. Energy balance and ovarian follicle development prior to the first ovulation postpartum in dairy cows receiving three levels of dietary fat. Biol. Reprod. 1997, 56, 133-142. [CrossRef] [PubMed]

19. Sheldon, I.M.; Williams, E.J.; Miller, A.N.; Nash, D.M.; Herath, S. Uterine diseases in cattle after parturition. Vet. J. 2008, 176, 115-121. [CrossRef] [PubMed]

20. Moore, S.G.; Ericsson, A.C.; Poock, S.E.; Melendez, P.; Lucy, M.C. Hot topic: 16 S rRNA gene sequencing reveals the microbiome of the virgin and pregnant bovine uterus. J. Dairy Sci. 2017, 100, 4953-4960. [CrossRef]

21. Källerö, E.E. Uterine Physiology and Pathology in the Post-Partum Period in Ethiopian Cattle; Swedish University of Agricultural Sciences: Uppsala, Sweden, 2010; pp. 1-25.

22. Jeon, S.J.; Vieira-Neto, A.; Gobikrushanth, M.; Daetz, R.; Mingoti, R.D.; Parize, A.C.B.; de Freitas, S.L.; da Costa, A.N.L.; Bicalho, R.C.; Lima, S.; et al. Uterine microbiota progression from calving until establishment of metritis in dairy cows. Appl. Environ. Micr. 2015, 81, 6324-6332. [CrossRef] [PubMed]

23. Jeon, S.J.; Cunha, F.; Vieira-Neto, A.; Bicalho, R.C.; Lima, S.; Bicalho, M.L.; Galvão, K.N. Blood as a route of transmission of uterine pathogens from the gut to the uterus in cows. Microbiome 2017, 5, 109. [CrossRef] [PubMed]

24. LeBlanc, S.J.; Duffield, T.F.; Leslie, K.E.; Bateman, K.G.; Keefe, G.P.; Walton, J.S.; Johnson, W.H. Defining and diagnosing postpartum clinical endometritis and its impact on reproductive performance in dairy cows. J. Dairy Sci. 2002, 85, 2223-2236. [CrossRef]

25. Sheldon, I.M.; Owens, S.E.; Turner, M.L. Innate immunity and the sensing of infection, damage and danger in the female genital tract. J. Reprod. Immunol. 2017, 119, 67-73. [CrossRef] [PubMed]

26. Racicot, K.; Cardenas, I.; Wünsche, V.; Aldo, P.; Guller, S.; Means, R.; Mor, G. Viral infection of the pregnant cervix predisposes to ascending bacterial infection. J. Immun. 2013, 191, 934-941. [CrossRef] 
27. Lewis, G.S. Uterine health and disorders. J. Dairy Sci. 1997, 80, 984-994. [CrossRef]

28. LeBlanc, S.J.; Osawa, T.; Dubuc, J. Reproductive tract defense and disease in postpartum dairy cows. Theriogenology 2011, 76, 1610-1618. [CrossRef] [PubMed]

29. Onyango, J.; Deluna, C.; Blackie, N. Risk factors for postpartum uterine infections in dairy herds. Int. J. Livest. Res. 2014, 4, 29-40. [CrossRef]

30. Dubuc, J. Postpartum uterine diseases: Prevalence, impacts, and treatments. Adv. Dairy Technol. 2011, 23, $255-267$.

31. Stinson, L.F.; Boyce, M.C.; Payne, M.S.; Keelan, J.A. The not-so-sterile Womb: Evidence that the human fetus is exposed to bacteria prior to birth. Front. Microbiol. 2019, 10, 1124. [CrossRef]

32. Ardissone, A.N.; de la Cruz, D.M.; Davis-Richardson, A.G.; Rechcigl, K.T.; Li, N.; Drew, J.C.; Murgas-Torrazza, R.; Sharma, R.; Hudak, M.L.; Triplett, E.W.; et al. Meconium microbiome analysis identifies bacteria correlated with premature birth. PLoS ONE 2014, 9, e90784. [CrossRef]

33. D'Argenio, V. The prenatal microbiome: A new player for human health. High Throughput 2018, 7, 38. [CrossRef]

34. Otero, C.; De Ruiz, C.S.; Ibañez, R.; Wilde, O.R.; De Ruiz Holgado, A.A.P.; Nader-Macias, M.E. Lactobacilli and enterococci isolated from the bovine vagina during the estrous cycle. Sci. Direct. Anaerobe 1999, 5, 305-307. [CrossRef]

35. Machado, V.S.; Oikonomou, G.; Bicalho, M.L.S.; Knauer, W.A.; Gilbert, R.; Bicalho, R.C. Investigation of postpartum dairy cows' uterine microbial diversity using metagenomic pyrosequencing of the 16S rRNA gene. Vet. Microbiol. 2012, 159, 460-469. [CrossRef]

36. Wang, Y.; Ametaj, B.N.; Ambrose, D.J.; Gänzle, M.G. Characterisation of the bacterial microbiota of the vagina of dairy cows and isolation of pediocin producing Pediococcus acidilactici. BMC Microbiol. 2013, 13, 1-11. [CrossRef]

37. Knudsen, L.R.; Karstrup, C.C.; Pedersen, H.G.; Agerholm, J.S.; Jensen, T.K.; Klitgaard, K. Revisiting bovine pyometra-new insights into the disease using a culture-independent deep sequencing approach. Vet. Microbiol. 2015, 175, 319-324. [CrossRef]

38. Swartz, J.D.; Lachman, M.; Westveer, K.; O'Neill, T.; Geary, T.; Kott, R.W.; Berardinelli, J.G.; Hatfield, P.G.; Thomson, J.M.; Roberts, A.; et al. Characterization of the vaginal microbiota of ewes and cows reveals a unique microbiota with low levels of lactobacilli and near-neutral pH. Front. Vet. Sci. 2014, 1, 19. [CrossRef] [PubMed]

39. Ravel, J.; Gajer, P.; Abdo, Z.; Schneider, G.M.; Koenig, S.S.K.; McCulle, S.L.; Karlebach, S.; Gorle, R.R.; Russell, J.; Tacket, C.O.; et al. Vaginal microbiome of reproductive-age women. Proc. Natl. Acad. Sci. USA 2011, 108, 4680-4687. [CrossRef] [PubMed]

40. O'Halan, D.E.; Moench, T.R.; Cone, R.A. Vaginal $\mathrm{pH}$ and microbicidal lactic acid when lactobacilli dominate the microbiota. PLOS ONE 2013, 8, e80074.

41. Li, J.; McCormick, J.; Bocking, A.; Reid, G. Importance of vaginal microbe in reproductive health. Reprod. Sci. 2012, 19, 235-242. [CrossRef]

42. Galvão, K.N.; Bicalho, R.C.; Jeon, S.J. Symposium review: The uterine microbiome associated with the development of uterine disease in dairy cows. J. Dairy Sci. 2019, 102, 11786-11797. [CrossRef]

43. Griffin, J.F.; Hartigan, P.J.; Nunn, W.R. Non-specific uterine infection and bovine fertility. I. Infection patterns and endometritis during the first seven weeks post-partum. Theriogenology 1974, 1, 91-106. [CrossRef]

44. Ruder, C.A.; Sasser, R.G.; Williams, R.J.; Ely, J.K.; Bull, R.C.; Butler, J.E. Uterine infections in the postpartum cow: I. Effect of dietary crude protein restriction. Theriogenology 1981, 15, 561-572. [CrossRef]

45. Bonnett, B.N.; Martin, S.W.; Gannon, V.P.; Miller, R.B.; Etherington, W.G. Endometrial biopsy in Holstein-Friesian dairy cows. III. Bacteriological analysis and correlations with histological findings. Can. J. Vet. Res. 1991, 55, 168-173.

46. Miranda-CasoLuengo, R.; Lu, J.; Williams, E.J.; Miranda-CasoLuengo, A.A.; Carrington, S.D.; Evans, A.C.O.; Meijer, W.G. Delayed differentiation of vaginal and uterine microbiomes in dairy cows developing postpartum endometritis. PLoS ONE 2019, 14, e0200974. [CrossRef]

47. Herthelius, M.; Gorbach, S.L.; Mollby, R.; Nord, C.E.; Pettersson, L.; Winberg, J. Elimination of vaginal colonization with Escherichia coli by administration of indigenous flora. Infect. Immun. 1989, 57, 2447-2451. [CrossRef]

48. Santos, T.M.A.; Bicalho, R.C. Diversity and succession of bacterial communities in the uterine fluid of postpartum metritic, endometritic and healthy dairy cows. PLoS ONE 2012, 7, e53048. [CrossRef] [PubMed]

49. Jost, B.H.; Billington, S.J. Arcanobacterium pyogenes: Molecular pathogenesis of an animal opportunist. Antonie Van Leeuwenhoek 2005, 88, 87-102. [CrossRef] [PubMed]

50. Jost, B.H.; Songer, J.G.; Billington, S.J. An Arcanobacterium (Actinomyces) pyogenes mutant deficient in production of the poreforming cytolysin pyolysin has reduced virulence. Infect. Immun. 1999, 67, 1723-1728. [CrossRef] [PubMed]

51. Deng, Q.; Odhiambo, J.F.; Farooq, U.; Lam, T.; Dunn, S.M.; Ametaj, B.N. Intravaginal Lactic Acid Bacteria Modulated Local and Systemic Immune Responses and Lowered the Incidence of Uterine Infections in Periparturient Dairy Cows. PhD Thesis, University of Alberta, Edmonton, AB, Canada, 2014; pp. 1-223.

52. Genís, S.; Sánchez-Chardi, A.; Bach, A.; Arís, A. Potential modulation of the toxic effects of Escherichia coli in bovine endometrium by lactic acid bacteria. Theriogenology 2016, 85, 625-637. [CrossRef]

53. Sheldon, I.M.; Rycroft, A.N.; Dogan, B.; Craven, M.; Bromfield, J.J.; Chandler, A.; Roberts, M.H.; Price, S.B.; Gilbert, R.O.; Simpso, K.W. Specific strains of Escherichia coli are pathogenic for the endometrium of cattle and cause pelvic inflammatory disease in cattle and mice. PLoS ONE 2010, 5, e9192. [CrossRef]

54. DebRoy, C.; Maddox, C.W. Identification of virulence attributes of gastrointestinal Escherichia coli isolates of veterinary significance. Anim. Health Res. Rev. 2001, 2, 129-140. [CrossRef] 
55. Wright, W.F.; Shiner, C.N.; Ribes, J.A. Lemierre syndrome. South. Med. J. 2012, 105, 283-288. [CrossRef]

56. Tan, Z.L.; Nagaraja, T.G.; Chengappa, M.M.; Smith , J.S. Biological and biochemical characterization of Fusobacterium necrophorum leukotoxin. Am. J. Vet. Res. 1994, 55, 515-521.

57. Tadepalli, S.; Stewart, G.C.; Nagaraja, T.G.; Narayanan, S.K. Human Fusobacterium necrophorum strains have a leukotoxin gene and exhibit leukotoxic activity. J. Med. Microbiol. 2008, 57, 225-231. [CrossRef]

58. Shinjo, T.; Fujisawa, T.; Mitsuoka, T. Proposal of Two Subspecies of Fusobacterium necrophorum (Flügge) Moore and Holdeman: Fusobacterium necrophorum subsp. necrophorum subsp. nov., nom. rev. (ex Flügge 1886), and Fusobacterium necrophorum subsp. funduliforme subsp. nov., nom. rev. (ex Hallé 1898). Int. J. Syst. Bacteriol. 1991, 41, 395-397.

59. Narayanan, S.K.; Nagaraja, T.G.; Chengappa, M.M.; Stewart, G.C. Cloning, sequencing, and expression of the leukotoxin gene from Fusobacterium necrophorum. Infect. Immunol. 2001, 69, 5447-5455. [CrossRef] [PubMed]

60. Caroff, M.; Karibian, D. Structure of bacterial lipopolysaccharides. Carbohydr. Res. 2003, 338, 2431-2447. [CrossRef] [PubMed]

61. Markusfeld, O. Factors responsible for post parturient metritis in dairy cattle. Vet. Rec. 1984, 114, 539-542. [CrossRef] [PubMed]

62. Földi, J.; Kulcsár, M.; Pécsi, A.; Huyghe, B.; de Sa, C.; Lohuis, J.A.; Huszenicza, G. Bacterial complications of postpartum uterine involution in cattle. Anim. Reprod. Sci. 2006, 96, 265-281. [CrossRef]

63. Konyves, L.; Szenci, O.; Jurkovich, V.; Tegzes, L.; Tirián, A.; Solymosi, N.; Gyulay, G.; Brydl, E. Risk assessment of postpartum uterine disease and consequences of puerperal metritis for subsequent metabolic status, reproduction and milk yield in dairy cows. Acta Vet. Hung. 2009, 57, 155-169. [CrossRef]

64. Sheldon, I.M.; Noakes, D.E.; Rycroft, A.N.; Pfeiffer, D.U.; Dobson, H. Influence of uterine bacterial contamination after parturition on ovarian dominant follicle selection and follicle growth and function in cattle. Reproduction 2002, 123, 837-845. [CrossRef]

65. Bicalho, M.L.; Machado, V.S.; Oikonomou, G.; Gilbert, R.O.; Bicalho, R.C. Association between virulence factors of Escherichia coli, Fusobacterium necrophorum, and Arcanobacterium pyogenes and uterine diseases of dairy cows. Vet. Microbiol. 2012, 157, 125-131. [CrossRef]

66. Jeon, S.J.; Galvão, K.N. An advanced understanding of uterine microbial ecology associated with metritis in dairy cows. Genom. Inform. 2018, 16, e21. [CrossRef]

67. Herath, S.; Lilly, S.T.; Fischer, D.P.; Williams, E.J.; Dobson, H.; Bryant, C.E.; Sheldon, I.M. Bacterial lipopolysaccharide induces an endocrine switch from prostaglandin F2alpha to prostaglandin $E_{2}$ in bovine endometrium. Endocrinology 2009, 150, 1912-1920. [CrossRef]

68. Huzzey, J.M.; Veira, D.M.; Weary, D.M.; von Keyserlingk, M.A.G. Prepartum behavior and dry matter intake identify dairy cows at risk for metritis. J. Dairy Sci. 2017, 7, 3220-3233. [CrossRef]

69. Mateus, L.; da Costa, L.; Bernardo, F.; Silva, J.R. Influence of puerperal uterine infection on uterine involution and postpartum ovarian activity in dairy cows. Reprod. Domest. Anim. 2002, 37, 31-35. [CrossRef] [PubMed]

70. Beckwith-Cohen, B.; Koren, O.; Blum, S.; Elad, D. Variations in vaginal pH in dairy cattle associated with parity and the periparturient period. Isr. J. Vet. Med. 2012, 67, 55-59.

71. Bondurant, R.H. Inflammation in the bovine female reproductive tract. J. Anim. Sci. 1999, 77, 101-110. [CrossRef] [PubMed]

72. Pleticha, S.; Drillich, M.; Heuwieser, W. Evaluation of the Metricheck device and the gloved hand for the diagnosis of clinical endometritis in dairy cows. J. Dairy Sci. 2009, 92, 5429-5435. [CrossRef] [PubMed]

73. McDougall, S.; Macaulay, R.; Compton, C. Association between endometritis diagnosis using a novel intravaginal device and reproductive performance in dairy cattle. Anim. Reprod. Sci. 2007, 99, 9-23. [CrossRef]

74. Gilbert, R.O. Management of reproductive disease in dairy cows. Vet. Clin. N. Am. Food Anim. Pract. 2016, 32, 387-410. [CrossRef]

75. Deguillaume, L.; Geffré, A.; Desquilbet, L.; Dizien, A.; Thoumire, S.; Vornière, C. Effect of endocervical inflammation on days to conception in dairy cows. J. Dairy Sci. 2012, 95, 1776-1783. [CrossRef]

76. Kasimanickam, R.; Duffield, T.F.; Foster, R.A.; Gartley, C.J.; Leslie, K.E.; Walton, J.S.; Johnson, W.H. Endometrial cytology and ultrasonography for the detection of subclinical endometritis in postpartum dairy cows. Theriogenology 2004, 62, 9-23. [CrossRef]

77. Gilbert, R.O.; Shin, S.T.; Guard, C.L.; Erb, H.N.; Frajblat, M. Prevalence of endometritis and its effects on reproductive performance of dairy cows. Theriogenology 2005, 64, 1879-1888. [CrossRef]

78. Wagener, K.; Gabler, C.; Drillich, M. A review of the ongoing discussion about definition, diagnosis and pathomechanism of subclinical endometritis in dairy cows. Theriogenology 2017, 94, 21-30. [CrossRef]

79. Ball, B.; Shin, S.; Patten, V.; Lein, D.; Woods, G. Use of a low-volume uterine flush for microbiologic and cytologic examination of the mare's endometrium. Theriogenology 1988, 29, 1269-1283. [CrossRef]

80. Cocchia, N.; Paciello, O.; Auletta, L.; Uccello, V.; Silvestro, L.; Mallardo, K. Comparison of the cytobrush, cottonswab, and lowvolume uterine flush techniques to evaluate endometrial cytology for diagnosing endometritis in chronically infertile mares. Theriogenology 2012, 77, 89-98. [CrossRef] [PubMed]

81. Pak, H.; Yokota, S.; Teplitz, R.; Shaw, S.; Werner, J. Rapid staining techniques employed in fine needle aspirations of the lung. Acta Cytol. 1980, 25, 178-184.

82. Yang, G.; Alvarez, I.I. Ultrafast Papanicolaou stain. An alternative preparation for fine needle aspiration cytology. Acta Cytol. 1994, 39, 55-60.

83. Peeler, E.J.; Otte, M.J.; Esslemont, R.J. Recurrence odds ratios for periparturient diseases and reproductive traits of dairy cows. Br. Vet. J. 1994, 150, 481-488. [CrossRef] 
84. Drillich, M.; Raab, D.; Wittke, M.; Heuwieser, W. Treatment of chronic endometritis in dairy cows with an intrauterine application of enzymes. Theriogenology 2005, 63, 1811-1823. [CrossRef]

85. Drillich, M.; Reichert, U.; Mahlstedt, M.; Heuwieser, W. Comparison of two strategies for systemic antibiotic treatment of dairy cows with retained fetal membranes: Preventive vs. selective treatment. J. Dairy Sci. 2006, 89, 1502-1508. [CrossRef]

86. Hammon, D.S.; Evjen, I.M.; Dhiman, T.R.; Goff, J.P.; Walters, J.L. Neutrophil function and energy status in Holstein cows with uterine health disorders. Vet. Immunol. Immunopathol. 2006, 113, 21-29. [CrossRef]

87. Barlund, C.S.; Carruthers, T.D.; Waldner, C.L.; Palmer, C.W. A comparison of diagnostic techniques for postpartum endometritis in dairy cattle. Theriogenology 2008, 69, 714-723. [CrossRef]

88. Raab, D. Evaluation of the Cytobrush Method for the Detection of Subclinical Endometritis and the Effect of a Subclinically Inflamed Uterus on Reproductive Performance in Dairy Cows. Ph.D. Thesis, Free University of Berlin, Berlin, Germany, 2004; pp. $1-112$.

89. Olson, J.D.; Ball, L.; Mortimer, R.G.; Farin, P.W.; Adney, W.S.; Huffman, E.M. Aspects of bacteriology and endocrinology of cows with pyometra and retained fetal membranes. Am. J. Vet. Res. 1984, 45, 2251-2255.

90. Santos, T.M.A.; Gilbert, R.O.; Bicalho, R.C. Metagenomic analysis of the uterine bacterial microbiota in healthy and metritic postpartum dairy cows. J. Dairy Sci. 2011, 94, 291-302. [CrossRef] [PubMed]

91. Ochiel, D.O.; Fahey, J.V.; Ghosh, M.; Haddad, S.N.; Wira, C.R. Innate Immunity in the female reproductive tract: Role of sex hormones in regulating uterine epithelial cell protection against pathogens. Curr. Womens Health Rev. 2008, 4, 102-117. [CrossRef] [PubMed]

92. Capaldo, C.T.; Nusrat, A. Cytokine regulation of tight junctions. Biochim. Biophys. Acta 2009, 1788, 864-871. [CrossRef] [PubMed]

93. Farage, M.A.; Miller, K.W.; Gerberick, G.F.; Saito, F.H.; Ledge, W.J.; Witkin, S.S. Innate immunity in the lower female mucosal tract. J. Steroids Hormon. Sci. 2011, 2, 106. [CrossRef]

94. Gipson, I.K. Mucins of the human endocervix. Front. Biosci. 2001, 6, D1245-D1255. [CrossRef]

95. Andersch-Bjorkman, Y.; Thomsson, K.A.; Holmen Larsson, J.M.; Ekerhovd, E.; Hansson, G.C. Large scale identification of proteins, mucins, and their oglycosylation in the endocervical mucus during the menstrual cycle. Mol. Cell Proteom. 2007, 6, 708-716. [CrossRef]

96. Huggins, G.R.; Preti, G. Vaginal odors and secretions. Clin. Obstet. Gynecol. 1981, 24, 355-377. [CrossRef]

97. Herath, S.; Fischer, D.P.; Werling, D.; Williams, E.J.; Lilly, S.T.; Dobson, H.; Bryant, C.E.; Sheldon, I.M. Expression and function of Toll-like receptor 4 in the endometrial cells of the uterus. Endocrinology 2006, 147, 562-570. [CrossRef]

98. Hart, K.M.; Murphy, A.J.; Barrett, K.T.; Wira, C.R.; Guyre, P.M.; Pioli, P.A. Functional expression of pattern recognition receptors in tissues of the human female reproductive tract. J. Reprod. Immunol. 2009, 80, 33-40. [CrossRef]

99. Fazeli, A.; Bruce, C.; Anumba, D.O. Characterization of toll-like receptors in the female reproductive tract in humans. Hum. Reprod. 2005, 20, 1372-1378. [CrossRef]

100. Mackay, I.; Rosen, F.S. Advances in immunology. N. Engl. J. Med. 2000, 343, 338-344.

101. Janeway, C.A., Jr.; Medzhitov, R. Innate immune recognition. Ann. Rev. Immunol. 2002, 20, 197-216. [CrossRef] [PubMed]

102. Tjabringa, G.S.; Vos, J.B.; Olthuis, D.; Ninaber, D.K.; Rabe, K.F.; Schalkwijk, J. Host defense effector molecules in mucosal secretions. Immunol. Med. Microbiol. 2005, 45, 151-158. [CrossRef] [PubMed]

103. Wiesner, J.; Vilcinskas, A. Antimicrobial peptides: The ancient arm of the human immune system. Virulence 2010, 1, 440-464. [CrossRef] [PubMed]

104. Bowdish, D.M.; Davidson, D.J.; Hancock, R.E. Immunomodulatory properties of defensins and cathelicidins. Curr. Top. Microbiol. Immunol. 2006, 306, 27-66. [PubMed]

105. Amjadi, F.; Salehi, E.; Mehdizadeh, M.; Aflatoonian, R. Role of the innate immunity in the female reproductive tract. Adv. Biom. Res. 2014, 3, 1-12.

106. Teng, T.S.; Ji, A.L.; Ji, X.Y.; Li, Y.Z. Neutrophils and immunity: From bactericidal action to being conquered. J. Immunol. Res. 2017, 2017, 9671604. [CrossRef]

107. Galvão, K.N.; Felippe, M.J.; Brittin, S.B.; Sper, R.; Fraga, M.; Galvao, J.S.; Caixeta, L.; Guard, C.L.; Ricci, A.; Gilbert, R.O. Evaluation of cytokine expression by blood monocytes of lactating Holstein cows with or without postpartum uterine disease. Theriogenology 2012, 77, 356-372. [CrossRef]

108. Duque, G.A.; Fukuda, M.; Descoteaux, A. Synaptotagmin XI regulates phagocytosis and cytokine secretion in macrophages. J. Immunol. 2013, 190, 173745.

109. Cobb, S.P.; Watson, E.D. Immunohistochemical study of immune cells in the bovine endometrium at different stages of the oestrous cycle. Res. Vet. Sci. 1995, 59, 238-241. [CrossRef]

110. Beutler, B.A. The role of tumor necrosis factor in health and disease. J. Rheu. 1999, 57, 16-21.

111. Kasimanickam, R.K.; Kasimanickam, V.R.; Olsen, J.R.; Jeffress, E.J.; Moore, D.A.; Kastelic, L.P. Associations among serum pro- and anti-inflammatory cytokines, metabolic mediators, body condition, and uterine disease in postpartum dairy cows. Rep. Biol. Endocrinol. 2013, 11, 103. [CrossRef] [PubMed]

112. Herath, S.; Lilly, S.T.; Santos, N.R.; Gilbert, R.O.; Goetze, L.; Bryant, C.E.; White, J.O.; Cronin, J.; Sheldon, I.M. Expression of genes associated with immunity in the endometrium of cattle with disparate postpartum uterine disease and fertility. Reprod. Biol. Endocrinol. 2009, 7, 55. [CrossRef] [PubMed] 
113. Hickey, D.K.; Patel, M.V.; Fahey, J.V.; Wira, C.R. Innate and adaptive immunity at mucosal surfaces of the female reproductive tract: Stratification and integration of immune protection against the transmission of sexually transmitted infections. J. Reprod. Immunol. 2011, 88, 185-194. [CrossRef] [PubMed]

114. Lieberman, J. The ABCs of granule-mediated cytotoxicity: New weapons in the arsenal. Nat. Rev. Immunol. 2003, 3, 361-370. [CrossRef]

115. Iijima, N.; Linehan, M.M.; Zamora, M.; Butkus, D.; Dunn, R.; Kehry, M.R.; Laufer, T.M.; Iwasaki, A. Dendritic cells and B cells maximize mucosal Th1 memory response to herpes simplex virus. J. Exp. Med. 2008, 205, 3041-3052. [CrossRef]

116. Nakanishi, Y.; Lu, B.; Gerard, C.; Iwasaki, A. CD8(+) T lymphocyte mobilization to virus-infected tissue requires CD4(+) T-cell help. Nature 2009, 462, 510-513. [CrossRef]

117. Johansson, E.; Rask, C.; Fredriksson, M.; Eriksson, K.; Czerkinsky, C.; Holmgren, J. Antibodies and antibody-secreting cells in the female genital tract after vaginal or intranasal immunization with cholera toxin B subunit or conjugates. Infect. Immun. 1998, 66, 514-520. [CrossRef]

118. Kutteh, W.H.; Mestecky, J. Secretory immunity in the female reproductive tract. Am. J. Reprod. Immunol. 1994, 31, 40-46. [CrossRef]

119. Kutteh, W.H.; Hatch, K.D.; Blackwell, R.E.; Mestecky, J. Secretory immune system of the female reproductive tract: I. Immunoglobulin and secretory component-containing cells. Obstet. Gynecol. 1988, 71, 56-60.

120. Crowley-Nowick, P.A.; Bell, M.; Edwards, R.P.; McCallister, D.; Gore, H.; Kanbour-Shakir, A.; Mestecky, J.; Partridge, E.E. Normal uterine cervix: Characterization of isolated lymphocyte phenotypes and immunoglobulin secretion. Am. J. Reprod. Immunol. 1995, 34, 241-247. [CrossRef] [PubMed]

121. Veiga-Parga, T. Regulatory T cells and their role in animal disease. Vet. Pathol. 2016, 53, 737-745. [CrossRef] [PubMed]

122. Cunha, P.; Vern, Y.L.; Gitton, C.; Germon, P.; Foucras, G.; Rainard, P. Expansion, isolation and first characterization of bovine Th17 lymphocytes. Sci. Rep. 2019, 9, 16115. [CrossRef] [PubMed]

123. Korn, T.; Bettelli, E.; Oukka, M.; Kuchroo, V.K. IL-17 and Th17 cells. Annu. Rev. Immunol. 2009, 27, 485-517. [CrossRef] [PubMed]

124. Feinen, B.; Jerse, A.E.; Gaffen, S.L.; Russell, M.W. Critical role of Th17 responses in a murine model of Neisseria gonorrhoeae genital infection. Mucosal Immunol. 2010, 3, 312-321. [CrossRef] [PubMed]

125. Nakashima, A.; Ito, M.; Shima, M.; Bac, N.D.; Hidaka, T.; Saito, S. Accumulation of IL-17-positive cells in decidua of inevitable abortion cases. Am. J. Reprod. Immunol. 2010, 64, 4-11. [CrossRef] [PubMed]

126. Scurlock, A.M.; Frazer, L.C.; Andrews, C.W., Jr.; O'Connell, C.M.; Foote, I.P.; Bailey, S.L.; Chandra-Kuntal, K.; Kollis, J.K.; Darville, T. IL-17 contributes to generation of Th1 immunity and neutrophil recruitment during Chlamydia muridarum genital tract infection but is not required for macrophage influx or normal resolution of infection. Infect. Immun. 2011, 79, 1349-1362. [CrossRef] [PubMed]

127. Jeon, S.J.; Lima, F.S.; Vieira-Neto, A.; Machado, V.S.; Lima, S.F.; Bicalho, R.C.; Santos, J.E.; Galvão, K.N. Shift of uterine microbiota associated with antibiotic treatment and cure of metritis in dairy cows. Vet. Microbiol. 2018, 214, 132-139. [CrossRef]

128. Sequin, B.E.; Morrow, D.A.; Louis, T.M. Luteolysis, luteostasis, and the effect of prostaglandin F $2 \alpha$ in cows after endometrial irritation. Am. J. Vet. Res. 1974, 35, 57-61.

129. Gustafsson, B.K. Therapeutic strategies involving antimicrobial treatment of the uterus of large animals. Theriogenology 1984, 6 , 45-50. [CrossRef]

130. Olson, J.D.; Ball, L.; Mortimer, R.G. Therapy of postpartum uterine infections. Proc. Ann. Conv. Assoc. Bovine Prac. 1985, $17,85$.

131. Olson, J.D.; Bretzlaff, K.N.; Mortimer, R.G.; Ball, L. The metritis-pyometra complex. In Current Therapy in Theriogenology; Morrow, D.A., Ed.; Saunders Elsevier: St. Louis, MO, USA, 1986; Volume 2, pp. 227-236.

132. Kaneene, J.B.; Coe, P.H.; Smith, J.H.; Rapnicki, P.; Smith, C.L.; Gerloff, B.; Morrow, D.A. Drug residues in milk after intrauterine injection of oxytetracycline, lincomycin-spectinomycin, and povidoneiodine in cows with metritis. Am. J. Vet. Res. 1986, 47, 1363-1365. [PubMed]

133. Pulfer, K.W.; Riese, R.L. Treatment of Postpartum Metritis in Dairy Cows. Iowa State Univ. Vet. 1991, 53, 6.

134. Pyörälä, S.; Taponen, J.; Katila, T. Use of antimicrobials in the treatment of reproductive diseases in cattle and horses. Reprod. Domest. Anim. 2014, 49, 16-26. [CrossRef]

135. Haimerl, P.; Heuwieser, W. Invited review: Antibiotic treatment of metritis in dairy cows: A systematic approach. J. Dairy Sci. 2014, 97, 6649-6661. [CrossRef]

136. Haimerl, P.; Arlt, S.; Borchardt, S.; Heuwieser, W. Antibiotic treatment of metritis in dairy cows-A meta-analysis. J. Dairy Sci. 2017, 100, 3783-3795. [CrossRef]

137. Farney, J.K.; Mamedova, L.; Coetzee, J.; KuKanich, B.; Sordillo, L.M.; Stoakes, S.K.; Minton, J.E.; Hollis, L.C.; Bradford, B.J. Anti-inflammatory salicylate treatment alters the metabolic adaptations to lactation in dairy cattle. Am. J. Physiol Regul. Integr. Comp. Physiol. 2013, 305, R110e7. [CrossRef]

138. Montgomery, S.R.; Mamedova, L.K.; Zachut, M.; Kra, G.; Haussler, S.; Vaughn, M.; Gonzalez, J.; Bradford, B.J. Effects of sodium salicylate on glucose kinetics and insulin signaling in post-partum dairy cows. J. Dairy Sci. 2019, 102, 1617e29. [CrossRef]

139. Barragan, A.A.; Bas, S.; Hovingh, E.; Ludwikowski, A.; Takitch, S.; Zug, J.; Hann, S. Effects of a new preventive strategy with acetylsalicylic acid on uterine diseases and reproductive performance in dairy cows. J. Dairy Sci. 2019, $102,308$.

140. Newby, N.C.; Leslie, K.E.; Putnam Dingwell, H.D.; Kelton, D.F.; Weary, D.M.; Neuder, L.; Millman, S.T.; Duffield, T.F. The effects of periparturient administration of flunixin meglumine on the health and production of dairy cattle. J. Dairy Sci. 2017, $100,582 \mathrm{e}$. [CrossRef] 
141. Kehrli, M.E.; Goff, J.P.; Stevens, M.G.; Boone, T.C. Effects of granulocyte colony stimulating factor administration to periparturient cows on neutrophils and bacterial shedding. J. Dairy Sci. 1991, 74, 2448e58. [CrossRef]

142. Zinicola, M.; Korzec, H.; Teixeira, A.G.V.; Ganda, E.K.; Bringhenti, L.; Tomazi, A.; Gilbert, R.O.; Bicalho, R.C. Effects of pegbovigrastim administration on periparturient diseases, milk production, and reproductive performance of Holstein cows. J. Dairy Sci. 2018, 101, 11199e217. [CrossRef] [PubMed]

143. Bicalho, M.L.S.; Zinicola, M.; Machado, V.S.; Lima, F.S.; Teixeira, A.G.V.; Narbus, C.; Xavier, M.R.; Higgins, H.; Bicalho, R.C. Effect of recombinant bovine interleukin-8 (rbIL-8) on health, metabolism, and lactation performance in Holstein cattle I: Production and functional characterization of rbIL-8 in vitro and in vivo. J. Dairy Sci. 2019, 102, 10304e15. [CrossRef]

144. Zinicola, M.; Bicalho, M.L.S.; Santin, T.; Marques, E.C.; Bisinotto, R.S.; Bicalho, R.C. Effects of recombinant bovine interleukin-8 (rbIL-8) treatment on health, metabolism, and lactation performance in Holstein cattle II: Postpartum uterine health, ketosis, and milk production. J. Dairy Sci. 2019, 102, 10316. [CrossRef] [PubMed]

145. LeBlanc, S.J. Review: Relationships between metabolism and neutrophil function in dairy cows in the peripartum period. Animal 2020, 14, s44-s54. [CrossRef] [PubMed]

146. Fuller, R. Probiotics in man and animals. J. Appl. Microbiol. 1989, 66, 365-378.

147. Barrons, R.; Tassone, D. Use of Lactobacillus probiotics for bacterial genitourinary infections in women: A review. Clin. Ther. 2008, 30, 453-468. [CrossRef]

148. Miller, E.A.; Beasley, D.E.; Dunn, R.R.; Archie, E.A. Lactobacilli dominance and vaginal pH: Why is the human vaginal microbiome unique? Front. Microbiol. 2016, 7, 1936. [CrossRef]

149. Wrenn, T.R.; Wood, J.R.; Bitman, J.; Brinsfield, T.H. Vaginal glycogen assay for oestrogen: Specificity and application to blood and urine. J. Reprod. Fertil. 1968, 16, 301-304. [CrossRef]

150. Ametaj, B.N.; Iqbal, S.; Selami, F.; Odhiambo, J.F.; Wang, Y.; Gaenzle, M.G.; Dunn, S.M.; Zebeli, Q. Intravaginal administration of lactic acid bacteria modulated the incidence of purulent vaginal discharges, plasma haptoglobin concentrations, and milk production in dairy cows. Res. Vet. Sci. 2014, 96, 365-370. [CrossRef]

151. Deng, Q.; Odhiambo, J.F.; Farooq, U.; Lam, T.; Dunn, S.M.; Ametaj, B.N. Intravaginal probiotics modulated metabolic status and improved milk production and composition of transition dairy cows. J. Anim. Sci. 2016, 94, 760-770. [CrossRef] [PubMed]

152. Ametaj, B.N. A New understanding of the causes of fatty liver in dairy cows. Adv. Dairy Technol. 2005, 17, 97-112.

153. Genís, S.; Sánchez-Chardi, A.; Bach, À.; Fàbregas, F.; Arís, A. A combination of lactic acid bacteria regulates Escherichia coli infection and inflammation of the bovine endometrium. J. Dairy Sci. 2017, 100, 479-492. [CrossRef] [PubMed]

154. Mercenier, A.; Pavan, S.; Pot, B. Probiotics as biotherapeutic agents: Present knowledge and future prospects. Curr. Pharm. Des. 2003, 9, 175-191. [CrossRef]

155. Reid, G. Potential preventive strategies and therapies in urinary tract infection. World J. Urol. 1999, 17, 359-363. [CrossRef]

156. Espeche, M.C.; Pellegrino, M.; Frola, I.; Larriestra, A.; Bogni, C.; Nader-Macias, M.E. Lactic acid bacteria from raw milk as potentially beneficial strains to prevent bovine mastitis. Anaerobe 2012, 18, 103-109. [CrossRef]

157. Reid, G. Probiotics for urogenital health. Nutr. Clin. Care 2002, 5, 3-8. [CrossRef]

158. Otero, M.C.; Morelli, L.; Nader-Macías, M.E. Probiotic properties of vaginal lactic acid 349 bacteria to prevent metritis in cattle. Lett. Appl. Microbiol. 2006, 43, 91-97. [CrossRef]

159. Rodríguez, C.; Cofré, J.V.; Sánchez, M.; Fernández, P.; Boggiano, G.; Castro, E. Lactobacilli isolated from vaginal vault of dairy and meat cows during progesteronic stage of estrous cycle. Anaerobe 2011, 17, 15-18. [CrossRef]

160. Dobson, A.; Cotter, P.D.; Ross, R.P.; Hill, C. Bacteriocin production: A probiotic trait? Appl. Environ. Microbiol. 2012, 78, 1-6. [CrossRef]

161. Gillor, O.; Giladi, I.; Riley, M.A. Persistence of colicinogenicEsche-richia coliin the mouse gastrointestinal tract. BMC Microbiol. 2009, 9, 165. [CrossRef] [PubMed]

162. Le Blay, G.; Lacroix, C.; Zihler, A.; Fliss, I. In vitro inhibition activity of nisin A, nisin Z, pediocin PA-1 and antibiotics against common intestinal bacteria. Lett. Appl. Microbiol. 2007, 45, 252-257. [CrossRef] [PubMed]

163. Servin, A.L. Antagonistic activities of lactobacilli and bifidobacteriaagainst microbial pathogens. FEMS Microbiol. Rev. 2004, 28, 405-440. [CrossRef] [PubMed]

164. Fajardo, A.; Martinez, J.L. Antibiotics as signals that trigger specific bacterial responses. Curr. Opin. Microbiol. 2008, 11, 161-167. [CrossRef]

165. Meijerink, M.; Wells, J.M. Identification of genetic loci in Lactobacillus plantarum that modulate the immune response of dendritic cells using comparative genome hybridization. PLoS ONE 2010, 5, e10632. [CrossRef]

166. van Hemert, S.; Meijerink, M.; Molenaar, D.; Bron, P.A.; de Vos, P.; Kleerebezem, M.; Wells, J.M.; Marco, M.L. Identification of Lactobacillus plantarum genes modulating the cytokine response of human peripheral blood mononuclear cells. BMC Microbiol. 2010, 10, 293. [CrossRef]

167. Bermudez-Brito, M.; Plaza-Díaz, J.; Muñoz-Quezada, S.; Gómez-Llorente, C.; Gil, A. Probiotic mechanisms of action. Ann. Nutr. Metab. 2012, 61, 160-174. [CrossRef]

168. Anderson, R.C.; Cookson, A.L.; McNabb, W.C.; Park, Z.; McCann, M.J.; Kelly, W.J.; Roy, N.C. Lactobacillus plantarum MB452 enhances the function of the intestinal barrier by increasing the expression levels of genes involved in tight junction formation. BMC Microbiol. 2010, 10, 316. [CrossRef]

169. Hummel, S.; Veltman, K.; Cichon, C.; Sonnen-born, U.; Schmidt, M.A. Differential targeting of the E-cadherin/ $\beta$-catenin complex by Gram-positive probiotic lactobacilli improves epithelial barrier function. Appl. Environ. Microbiol. 2012, 78, 1140-1147. [CrossRef] 
170. Juntunen, M.; Kirjavainen, P.V.; Ouwehand, A.C.; Salminen, S.J.; Isolauri, E. Adherence of probiotic bacteria to human intestinal mucus in healthy infants and during rotavirus infection. Clin. Diag. Lab. Immunol. 2001, 8, 293-296. [CrossRef]

171. Beachey, E.H. Bacterial adherence: Adhesin-receptor interactions mediating the attachment of bacteria to mucosal surfaces. J. Infect. Dis. 1981, 143, 325-345. [CrossRef] [PubMed]

172. Schiffrin, E.J.; Brassart, D.; Servin, A.L.; Rochat, F.; Donnet-Hughes, A. Immune modulation of blood leukocytes in humans by lactic acid bacteria: Criteria for strain selection. Am. J. Clin. Nutr. 1997, 66, 515S-520S. [CrossRef] [PubMed]

173. Buck, B.L.; Altermann, E.; Svingerud, T.; Klaenhammer, T.R. Functional analysis of putative adhesion factors in Lactobacillus acidophilus NCFM. Appl. Environ. Microbiol. 2005, 71, 8344-8351. [CrossRef] [PubMed]

174. Szachta, P.; Ignyś, I.; Cichy, W. An evaluation of the ability of the probiotic strain Lactobacillus rhamnosus GG to eliminate the gastrointestinal carrier state of vancomycin-resistant enterococci in colonized children. J. Clin. Gastroenterol. 2011, 45, 872-877. [CrossRef] [PubMed]

175. Manley, K.J.; Fraenkel, M.B.; Mayall, B.C.; Power, D.A. Probiotic treatment of vancomycin-resistant enterococci: A randomised controlled trial. Med. J. Aust. 2007, 186, 454-457. [CrossRef] [PubMed]

176. Tytgat, H.L.; Douillard, F.P.; Reunanen, J.; Douillard, F.P.; Rasinkangas, P.; Messing, M.; Reunanen, J.; Satokari, R.; Vanderleyden, J.; Dufrêne, Y.F.; et al. Lactobacillus rhamnosus GG outcompetes Enterococcus faecium via mucus-binding pili: Evidence for a novel and heterospecific probiotic mechanism. Appl. Environ. Microbiol. 2016, 82, 5756-5762. [CrossRef]

177. Collado, M.C.; Isolauri, E.; Salminen, S. Specific probiotic strains and their combinations counteract adhesion of Enterobacter sakazakii to intestinal mucus. FEMS Microbiol. Lett. 2008, 285, 58-64. [CrossRef]

178. Matsubara, V.H.; Bandara, H.M.; Ishikawa, K.H.; Mayer, M.P.; Samaranayake, L.P. The role of probiotic bacteria in managing periodontal disease: A systematic review. Expert Rev. Anti-Infect. Ther. 2016, 14, 643-655. [CrossRef]

179. Jørgensen, M.R.; Kragelund, C.; Jensen, P.Ø.; Keller, M.K.; Twetman, S. Probiotic Lactobacillus reuteri has antifungal effects on oral Candida species in vitro. J. Oral Microbiol. 2017, 9, 1274582. [CrossRef]

180. Ya, W.; Reifer, C.; Miller, L. Efficacy of vaginal probiotic capsules forrecurrent bacterial vaginosis: A double-blind, randomized, placebo-controlled study. Am. J. Obstet. Gynecol. 2010, 203, 120.e1-120.e6. [CrossRef]

181. Bisanz, J.E.; Seney, S.; McMillan, A.; Vongsa, R.; Koenig, D.; Wong, L.F.; Dvoracek, B.; Gloor, G.B.; Sumarah, M.; Ford, B.; et al. A systems biology approach investigating the, effect of probiotics on the vaginal microbiome and host responses in a double blind, placebo-controlled clinical trial of post-menopausal women. PLoS ONE 2014, 9, e104511. [CrossRef] [PubMed]

182. Heczko, P.B.; Tomusiak, A.; Adamski, P.; Jakimiuk, A.J.; Stefanski, G.; Mikolajczyk-Cichonska, A.; Suda-Szczurek, M.; Strus, M. Supplementation of standard antibiotic therapy with oral probioticsfor bacterial vaginosis and aerobic vaginitis: A randomised, double-blind, placebocontrolled trial. BMC Womens Health 2015, 15, 115. [CrossRef] [PubMed]

183. Pendharkar, S.; Brandsborg, E.; Hammarström, L.; Marcotte, H.; Larsson, P.G. Vaginal colonisation by probiotic lactobacilli and clinicaloutcome in women conventionally treated for bacterial vaginosisand yeast infection. BMC Infect. Dis. 2015, 15, 255. [CrossRef] [PubMed]

184. Verdenelli, M.; Cecchini, C.; Coman, M.; Silvi, S.; Orpianesi, C.; Coata, G.; Cresci, A.; Di Renzo, G.C. Impact of probiotic SYNBIO ${ }^{\circledR}$ administered by vaginal suppositories in promoting vaginal health of apparently healthy women. Curr. Microbiol. 2016, 73, 483-490. [CrossRef]

185. Stapleton, A.; Silvestroni, A.; Roberts, P.; Cox, M.; Hayden, H.; Brittnacher, M.; Miller, S.; Hooton, T. Robust and persistent vaginal coloniza-tion with LACTIN-V vaginal Lactobacillus crispatus probiotic in adouble-blind, placebo-controlled (DBPC) phase $2 \mathrm{~b}$ trial to preventrecurrent UTI (rUTI). Open Forum Infect. Dis. 2018, 26, 5.

186. Mezzasalma, V.; Manfrini, E.; Ferri, E.; Boccarusso, M.; Di Gennaro, P.; Schiano, I.; Michelotti, A.; Labra, M. Orally administered mul-tispecies probiotic formulations to prevent uro-genital infections: Arandomized placebo-controlled pilot study. Arch. Gynecol. Obstet. 2017, 295, 163-172. [CrossRef]

187. Salminen, S. Lactic Acid Bacteria: Microbiology and Functional Aspects, 2nd ed.; Marcel Dekker: New York, NY, USA, 1998.

188. Alakomi, H.L.; Skytta, E.; Saarela, M.; Mattila-Sandholm, T.; Latva-Kala, K.; Helander, I.M. Lactic acid permeabilizes gramnegative bacteria by disrupting the outer membrane. Appl. Environ. Microbiol. 2000, 66, 2001-2005. [CrossRef]

189. De Keersmaecker, S.C.; Verhoeven, T.L.; Desair, J.; Marchal, K.; Vanderleyden, J.; Nagy, I. Strong antimicrobial activity of Lactobacillus rhamnosus GG against Salmonella typhimurium is due to accumulation of lactic acid. FEMS Microbiol. Lett. 2006, 259, 89-96. [CrossRef]

190. Makras, L.; Triantafyllou, V.; Fayol-Messaoudi, D.; Adriany, T.; Zoumpopoulou, G.; Tsakalidou, E.; Servin, A.; DeVuyst, L. Kinetic analysis of the antibacterial activity of probiotic lactobacilli towards Salmonella enterica serovar typhimurium reveals a role for lactic acid and other inhibitory compounds. Res. Microbiol. 2006, 157, 241-247. [CrossRef]

191. Ouwehand, A.C. Antimicrobial components from lactic acid bacteria. In Lactic Acid Bacteria: Microbiology and Functional Aspects; Salminen, S., von Wright, A., Eds.; Dekker: New York, NY, USA, 1998; pp. 139-159.

192. Russell, J.B.; Diez-Gonzalez, F. The effects of fermentation acids on bacterial growth. Adv. Microb. Physiol. 1998, 39, $205-234$.

193. William Leitch, E.C.; Stewart, C.S. Escherichia coli O157 and non-O157 isolates are more susceptible to L-lactate than to D-lactate. Appl. Environ. Microbiol. 2002, 68, 4676-4678. [CrossRef] [PubMed]

194. Dasari, S.; Rajendra, W.; Valluru, L. Evaluation of microbial enzymes in normal and abnormal cervi- covaginal fluids of cervical dysplasia: A case control study. BioMed Res. Int. 2014, 2014, 716346. [CrossRef] [PubMed] 
195. Moll, G.N.; Konings, W.N.; Driessen, A.J. Bacteriocins: Mechanism of membrane insertion and pore formation. Antonie Van Leeuwenhoek 1999, 76, 185-198. [CrossRef] [PubMed]

196. Flynn, S.; van Sinderen, D.; Thornton, G.M.; Holo, H.; Nes, I.F.; Collins, J.K. Characterization of the genetic locus responsible for the production of ABP-118, a novel bacteriocin produced by the probiotic bacterium Lactobacillus salivarius subsp. salivarius UCC118. Microbiology 2002, 148, 973-984. [CrossRef]

197. McAuliffe, O.; Ryan, M.P.; Ross, R.P.; Hill, C.; Breeuwer, P.; Abee, T. Lacticin 3147, a broad-spectrum bacteriocin which selectively dissipates the membrane potential. Appl. Environ. Microbiol. 1998, 64, 439-445. [CrossRef]

198. Rea, M.C.; Clayto, N.E.; O'Connor, P.M.; Shanahan, F.; Kiely, B.; Ross, R.P.; Hill, C. Antimicrobial activity of lacticin 3147 against clinical Clostridium difficile strains. J. Med. Microbio. 2007, 156, 940-946. [CrossRef]

199. Ryan, M.P.; Rea, M.C.; Hill, C.; Ross, R.P. An application in cheddar cheesemanufacture for a strain of Lactococcus lactis producing a novel broad-spectrum bacteriocin, lacticin 3147. Appl. Environ. Microbiol. 1996, 62, 612-619. [CrossRef]

200. Klebanoff, S.J.; Hillier, S.L.; Eschenbach, D.A.; Waltersdorph, A.M. Control of the microbial flora of the vagina by $\mathrm{H}_{2} \mathrm{O}_{2}$-generating lactobacilli. J. Infect. Dis. 1991, 164, 94-100. [CrossRef]

201. Aroutcheva, A.; Gariti, D.; Simon, M.; Shott, S.; Faro, J.; Simoes, J.A.; Gurguis, A.; Faro, S. Defense factors of vaginal lactobacilli. Am. J. Obstet. Gynecol. 2001, 185, 375-379. [CrossRef]

202. Antonio, M.A.; Hawes, S.E.; Hillier, S.L. The identification of vaginal Lactobacillus species and the demographic and microbiologic characteristics of women colonized by these species. J. Infect. Dis. 1999, 180, 1950-1956. [CrossRef]

203. Wasiela, M.; Krzemiński, Z.; Kalinka, J.; Brzezińska-Błaszczyk, E. Correlation between levels of selected cytokines in cervicovaginal fluid of women with abnormal vaginal bacterial flora. Med. Dosw. Mikrobiol. 2005, 57, 327-333.

204. Huang, B.; Fettweis, J.M.; Brooks, J.P.; Jefferson, K.K.; Buck, G.A. The changing landscape of the vaginal microbiome. Clin. Lab. Med. 2014, 34, 747-761. [CrossRef] [PubMed]

205. O'Hanlon, D.E.; Lanier, B.R.; Moench, T.R.; Cone, R.A. Cervicovaginal fluid and semen block the microbicidal activity of hydrogen peroxide produced by vaginal lactobacilli. BMC Infect. Dis. 2010, 10, 120. [CrossRef] [PubMed]

206. Rizzo, A.; Losacco, A.; Carratelli, C.R. Lactobacillus crispatus modulates epithelial cell defense against Candida albicans through toll-like receptors 2 and 4, interleukin 8 and human $\beta$-defensins 2 and 3. Immunol. Lett. 2013, 156, 102-109. [CrossRef] [PubMed]

207. Abramov, V.; Khlebnikov, V.; Kosarev, I.; Bairamova, G.; Vasilenko, R.; Suzina, N.; Machulin, A.; Sakulin, V.; Kulikova, N.; Vasilenko, N.; et al. Probiotic properties of Lactobacillus crispatus 2029: Homeostatic interaction with cervicovaginal epithelial cells and antagonistic activity to genitourinary pathogens. Probiotics Antimicrob. Proteins 2014, 6, 165-176. [CrossRef] [PubMed]

208. Rizzo, A.; Fiorentino, M.; Buommino, E.; Donnarumma, G.; Losacco, A.; Bevilacqua, N. Lactobacillus crispatus mediates antiinflammatory cytokine interleukin-10 induction in response to Chlamydia trachomatis infection in vitro. Int. J. Med. Microbiol. 2015, 305, 815-827. [CrossRef]

209. Yamamoto, H.S.; Xu, Q.; Fichorova, R.N. Homeostatic properties of Lactobacillus jensenii engineered as a live vaginal anti-HIV microbicide. BMC Microbiol. 2013, 13, 4. [CrossRef]

210. Eslami, S.; Hadjati, J.; Motevaseli, E.; Mirzaei, R.; Bonab, S.F.; Ansaripour, B.; Khoramizadeh, M.R. Lactobacillus crispatus strain SJ-3C-US induces human dendritic cells (DCs) maturation and confers an anti-inflammatory phenotype to DCs. APMIS 2016, 124, 697-710. [CrossRef] [PubMed]

211. Hearps, A.C.; Tyssen, D.; Srbinovski, D.; Bayigga, L.; Diaz, D.J.D.; Aldunate, M.; Cone, R.A.; Gugasyan, R.; Anderson, D.J.; Tachedjian, G. Vaginal lactic acid elicits an anti-inflammatory response from human cervicovaginal epithelial cells and inhibits production of pro-inflammatory mediators associated with HIV acquisition. Mucosal Immunol. 2017, 10, 1480-1490. [CrossRef]

212. Tachedjian, G.; Aldunate, M.; Bradshaw, C.S.; Cone, R.A. The role of lactic acid production by probiotic Lactobacillus species in vaginal health. Res. Microbiol. 2017, 168, 782-792. [CrossRef]

213. Hemalatha, R.; Mastromarino, P.; Ramalaxmi, B.A.; Balakrishna, N.V.; Sesikeran, B. Effectiveness of vaginal tablets containing lactobacilli versus $\mathrm{pH}$ tablets on vaginal health and inflammatory cytokines: A randomized, double-blind study. Eur. J. Clin. Microbiol. Infect. Dis. 2012, 31, 3097-3105. [CrossRef]

214. Mastromarino, P.; Hemalatha, R.; Barbonetti, A.; Cinque, B.; Cifone, M.G.; Tammaro, F.; Francavilla, F. Biological control of vaginosis to improve reproductive health. Indian J. Med. Res. 2014, 140, S91-S97.

215. De Gregorio, P.R.; Juárez Tomás, M.S.; Santos, V.; Nader-Macías, M.E. Beneficial lactobacilli: Effects on the vaginal tract in a murine experimental model. Antonie Van Leeuwenhoek 2012, 102, 569-580. [CrossRef]

216. Kummer, V.; Lány, P.; Masková, J.; Zralý, Z.; Canderle, J. Stimulation of cell defense mechanism of bovine endometrium by temporal colonization with selected strains of lactobacilli. Vet. Med. (Praha) 1997, 42, 217-224.

217. Boskey, E.R.; Telsch, K.M.; Whaley, K.J.; Moench, T.R.; Cone, R.A. Acid production by vaginal flora in vitro is consistent with the rate and extent of vaginal acidification. Infect. Immun. 1999, 67, 5170-5175. [CrossRef]

218. Aslim, B.; Kilic, E. Some probiotic properties of vaginal lactobacilli isolated from healthy women. Jpn. J. Infect. Dis. 2006, 59, $249-253$.

219. Borges, S.; Barbosa, J.; Silva, J.; Teixeira, P. Evaluation of characteristics of Pediococcus spp. to be used as a vaginal probiotic. J. Appl. Microbiol. 2013, 115, 527-538. [CrossRef]

220. Boris, S.; Barbés, C. Role played by lactobacilli in controlling the population of vaginal pathogens. Microbes Infect. 2000, 2, 543-546. [CrossRef]

221. Tomás, M.S.J.; Ocaña, V.S.; Wiese, B.; Nader-Macías, M.E. Growth and lactic acid production by vaginal Lactobacillus acidophilus CRL 1259, and inhibition of uropathogenic Escherichia coli. J. Med. Microbiol. 2003, 52, 1117-1124. [CrossRef] 